\title{
The effect of sea ice loss on sea salt aerosol concentrations and the radiative balance in the Arctic
}

\author{
H. Struthers ${ }^{1,2}$, A. M. L. Ekman ${ }^{3}$, P. Glantz ${ }^{1}$, T. Iversen ${ }^{4}$, A. Kirkevåg ${ }^{4}$, E. M. Mårtensson ${ }^{1}$, Ø. Seland ${ }^{4}$, and \\ E. D. Nilsson ${ }^{1}$ \\ ${ }^{1}$ Department of Applied Environmental Science, Stockholm University, Sweden \\ ${ }^{2}$ Bert Bolin Center for Climate Research, Stockholm University, Sweden \\ ${ }^{3}$ Department of Meteorology, Stockholm University, Sweden \\ ${ }^{4}$ Norwegian Meteorological Institute, Oslo, Norway
}

Received: 16 September 2010 - Published in Atmos. Chem. Phys. Discuss.: 24 November 2010

Revised: 14 March 2011 - Accepted: 29 March 2011 - Published: 13 April 2011

\begin{abstract}
Understanding Arctic climate change requires knowledge of both the external and the local drivers of Arctic climate as well as local feedbacks within the system. An Arctic feedback mechanism relating changes in sea ice extent to an alteration of the emission of sea salt aerosol and the consequent change in radiative balance is examined. A set of idealized climate model simulations were performed to quantify the radiative effects of changes in sea salt aerosol emissions induced by prescribed changes in sea ice extent. The model was forced using sea ice concentrations consistent with present day conditions and projections of sea ice extent for 2100. Sea salt aerosol emissions increase in response to a decrease in sea ice, the model results showing an annual average increase in number emission over the polar cap $\left(70-90^{\circ} \mathrm{N}\right)$ of $86 \times 10^{6} \mathrm{~m}^{-2} \mathrm{~s}^{-1}$ (mass emission increase of $23 \mu \mathrm{g} \mathrm{m}^{-2} \mathrm{~s}^{-1}$ ). This in turn leads to an increase in the natural aerosol optical depth of approximately $23 \%$. In response to changes in aerosol optical depth, the natural component of the aerosol direct forcing over the Arctic polar cap is estimated to be between -0.2 and $-0.4 \mathrm{~W} \mathrm{~m}^{-2}$ for the summer months, which results in a negative feedback on the system. The model predicts that the change in first indirect aerosol effect (cloud albedo effect) is approximately a factor of ten greater than the change in direct aerosol forcing although this result is highly uncertain due to the crude representation of Arctic clouds and aerosol-cloud interactions in the model. This study shows that both the natural aerosol direct and first indirect effects are strongly dependent on the
\end{abstract}

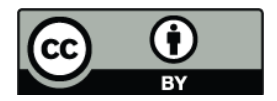

Correspondence to: H. Struthers (hamish.struthers@itm.su.se) surface albedo, highlighting the strong coupling between sea ice, aerosols, Arctic clouds and their radiative effects.

\section{Introduction}

The Arctic is currently experiencing rapid climate change (Lemke et al., 2007). A clear manifestation of this is the dramatic decline in Arctic sea ice thickness and extent observed over the past few decades (Comiso, 2003). Decreases in ice extent have been observed during the whole year with the largest rate of retreat (approximately $-7.5 \%$ per decade) occurring in late summer (Lemke et al., 2007). The continued loss of perennial Arctic sea ice portends future ice-free summers, which climate models project may happen within $50 \mathrm{yr}$ (Holland et al., 2006). A number of important ramifications for the atmosphere are anticipated to result from a seasonally ice-free Arctic ocean including changes in atmospheric circulation (Magnusdottir et al., 2004), precipitation and ocean storm tracks (Sewall and Sloan, 2004; Singarayer et al., 2006). In addition, Arctic ocean circulation and ocean and terrestrial ecosystems are expected to be strongly influenced by the retreat of Arctic sea ice (see Serreze et al., 2007, and references therein).

Understanding Arctic climate variability and climate change is a challenge because the Arctic climate is influenced both by local physical drivers, and by non-local changes at mid and low latitudes through changes in poleward heat transport, large scale variability patterns (Wang et al., 2009) and alterations to ocean circulation patterns (Mortiz et al., 2002). In addition, local feedbacks are important in the Arctic climate system (Vavrus, 2004; Winton, 2008). Climate

Published by Copernicus Publications on behalf of the European Geosciences Union. 
models have had limited success in accurately simulating the recent observed Arctic amplification of global climate change and there is poor agreement between model projections of future Arctic climate (Serreze and Francis, 2006). It is likely that this is due the failure of the current generation of models to accurately describe the complexity of the Arctic climate system and the strong interaction between local and non-local drivers and feedbacks.

The details and strengths of Arctic climate feedbacks are currently not well quantified. Perhaps the best studied Arctic feedback mechanism is the so called "snow/ice-albedo" feedback (see Winton, 2008, and references therein). Much focus has been placed on this mechanism because it was recognized early on (e.g. Kellog, 1973) that changes in the area of sea ice strongly affects the amount of reflected and absorbed solar radiation at the surface, in turn affecting the radiative balance. A basic outline of the snow/ice-albedo mechanism sees an increase in temperature causing a reduction in sea ice and snow extent. This in turn reduces the surface albedo, increasing the amount of sunlight absorbed by the Earth's surface leading to continued increases in temperature and therefore a positive feedback on the system.

In the present paper, we examine a second possible Arctic feedback relating climate change with an change of the emission of sea salt aerosol which has the potential to alter the radiative balance in the Arctic. Sea salt aerosol is the dominant primary aerosol source open oceans and is emitted into the atmosphere via bubble bursting at the ocean surface (Nilsson et al., 2001b; Lewis and Schwartz, 2004). The flux of sea salt aerosol is dependent on the sea ice fraction (Nilsson et al., 2001b) and therefore it follows that there is the potential for a significant perturbation of the Arctic tropospheric aerosol concentration and composition due to changes in sea ice cover. Nilsson et al. (2001b) suggested that this in turn would alter the radiative balance feeding back to Arctic temperatures and ultimately the sea ice cover, see Fig. 1. Assuming that the multi-year sea ice withdraws, its buffering influence on the surface water temperature will cease and sea surface temperatures may increase which will alter the sea spray production and possibly its climate forcing (Mårtensson et al., 2003, 2010). In general, the consequences of a change in sea salt aerosol emissions in the Arctic are not clear, despite several studies of the interaction between Arctic aerosols and climate (e.g. Jones et al., 2007; Quinn et al., 2007, 2008; Garrett et al., 2009; Kay and Gettelman, 2009).

The CAM-Oslo global climate model (Seland et al., 2008) is used here to study the proposed Arctic aerosolclimate feedback mechanism and its relationship to the Arctic snow/ice-albedo effect. Model results from a control simulation (present day) and perturbation simulations with prescribed ice free summer conditions are examined, with a focus on the radiative effects due to changes in sea ice extent and aerosol concentration. The version of the CAMOslo model used in this study does not couple the prognostic aerosol fields with the the simulated meteorology and so the radiative forcing due to the direct and the first indirect aerosol effect on climate (Twomey, 1977) was estimated by performing multiple calls to the radiative transfer scheme in the model. In addition, the model uses prescribed sea surface temperatures (SSTs) and sea ice fractions and only the indirect effect of aerosols in warm/liquid phase clouds is taken into account. Therefore this study should be considered an initial test to examine the strength of the Arctic aerosolclimate feedback and to evaluate its importance relative to the snow/ice-albedo effect.

The paper is organized as follows: the CAM-Oslo model is introduced in Sect. 2. The parameterization of sea salt emissions used in the model is described in Sect. 3, followed by a description of the experimental design in Sect. 4. The results of a set of four model experiments are discussed in Sect. 5 and finally Sect. 6 presents concluding remarks.

\section{CAM-Oslo model}

The CAM-Oslo model is described in detail by Seland et al. (2008). Briefly, the model is constructed using the CAM3 general circulation model (Collins et al., 2006) coupled to a detailed aerosol life-cycle module. The aerosol scheme includes prognostic aerosols (sulphate, particulate organic matter, black carbon, sea salt and mineral dust) and gaseous aerosol precursors (DMS and $\left.\mathrm{SO}_{2}\right)$ yielding sulphate $\left(\mathrm{SO}_{4}\right)$. The primary aerosol size distributions are approximated using a superposition of 11 log-normal modes which are subsequently modified via condensation and coagulation using a 44 sectional bin framework with process determined mixing states. The scheme includes treatment of aerosol production, transport and deposition (Iversen and Seland, 2002) and a parametrization of aerosol physics, aerosol and cloud optics and water uptake (Kirkevåg and Iversen, 2002). For relative humidities below $100 \%$, the hygroscopic growth of particles is modeled using a pre-calculated lookup table to estimate dry deposition. Large look-up tables are also used for the calculation of aerosol optics in the model, using relative humidity and a range of process specific aerosol concentrations as input parameters. The aerosol module is an extension of the parameterization described by Iversen and Seland (2002); Kirkevåg and Iversen (2002) and Kristjansson (2002).

The CAM-Oslo simulated aerosol fields and the direct and indirect aerosol radiative effects have been comprehensively evaluated through the AeroCom (Aerosol Comparisons between Observations and Models) international aerosol modeling initiative (Kinne et al., 2006; Penner et al., 2006; Schulz et al., 2006; Textor et al., 2006; Koch et al., 2009). See also Kirkevåg et al. (2008a,b). On global scales, the general characteristics of the aerosol fields and radiative forcings simulated by CAM-Oslo and its predecessor CCM-Oslo are within the range of the other models included in the AeroCom project (Kinne et al., 2006; Schulz et al., 2006; Quaas et al., 2009) although the model tends to underestimate the 


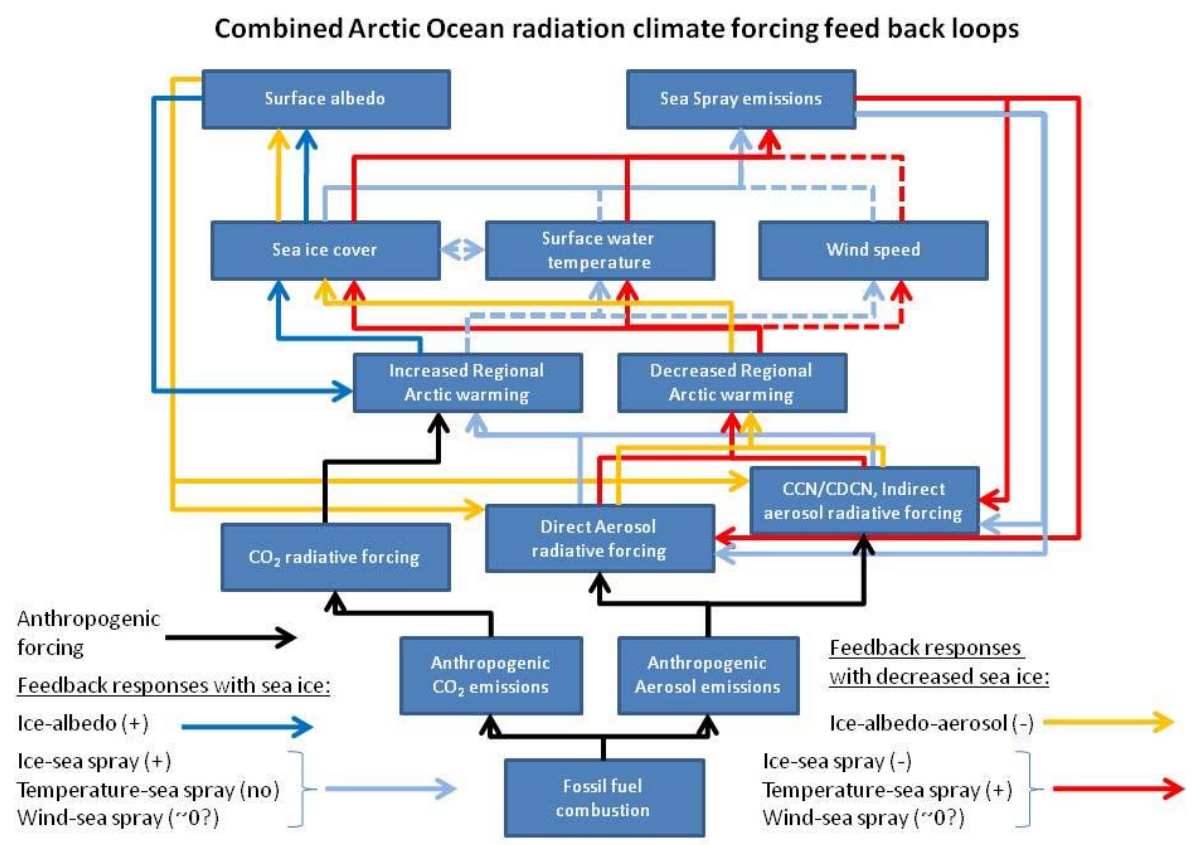

Fig. 1. Schematic representation of the processes involved in the Arctic sea ice-albedo and sea ice-aerosol feedback mechanisms. Black lines represent anthropogenic forcing and blue lines represent the usual sea ice-albedo positive feedback. Light blue and red lines represent the sea ice-aerosol feedbacks (positive and negative respectively) and the yellow lines indicate how the sea ice-albedo and sea ice-aerosol feedback loops are coupled. (+) Indicates an overall positive feedback effect, (-) an overall negative, and (0?) a small or uncertain feedback.

concentration of mineral dust away from major source regions (Seland et al., 2008). While displaying mid-range direct radiative forcing (DRF) at the ground surface, Schulz et al. (2006) found that the total "top-of-the-atmosphere" (TOA) anthropogenic aerosol DRF in CCM-Oslo was relatively high i.e. more positive $\left(-0.01 \mathrm{Wm}^{-2}\right)$ when compared with eight other models and the AeroCom average. The same holds true for CAM-Oslo, where the TOA DRF is $0.03 \mathrm{Wm}^{-2}$ (Seland et al., 2008). Despite this slightly positive DRF, the total aerosol absportion was found to be in relatively good agreement with ground based remote sensing retrievals (AERONET), where most AeroCom models have a clear negative bias (see http://nansen.ipsl.jussieu.fr/ AEROCOM/data.html)

The version of the CAM-Oslo model employed here calculates the aerosol direct effect through the use of precalculated lookup tables and 44 sectional bins to discretize the aerosol size distribution. The first aerosol indirect effect (Twomey, 1977) is also estimated using lookup tables (Kirkevåg et al., 2005). Cloud condensation nuclei (CCN) are activated at certain assumed maximum supersaturations. As in Kirkevåg et al. (2008b) we use the values $0.1 \%$ for stratiform clouds, $0.25 \%$ for convective clouds over ocean, and $0.8 \%$ in convective clouds over land. The cloud droplet number is simply assumed to equal the concentration of activated $\mathrm{CCN}$ at the given super-saturation. The aerosol radiative effects are calculated off-line in the simulations carried out here and therefore, the influence of changes in aerosol concentration and composition do not feed back to changes in the climate simulated by the model.

For this study, the model was configured using the Eulerian dynamical core at T42 spectral truncation (approximately $2.8^{\circ} \times 2.8^{\circ}$ on a Gaussian grid), a hybrid $\eta$-vertical coordinate with 26 levels. Further details of the experiments carried out and boundary conditions employed, including the prescribed SSTs and sea ice concentrations, are provided in Sect. 4. Arctic atmospheric circulation biases in CAM3 have previously been noted (e.g. Hurrell et al., 2005; Hack et al., 2006; Deweaver and Bitz, 2006). These biases in turn may affect the results presented below due to unrealistic meridional transport of aerosols into or out of the Arctic region. In addition, there are inherent problems with the representation of atmospheric transport in general circulation models (GCMs), in particular the vertical transport, which adds to the uncertainty in the modeled aerosol distributions. It is difficult to directly quantify how these issues will influence the results shown below. We thus simply note that the conclusions drawn here are based on output from a single model which, in common with all GCMs, is not completely unbiased with respect to the real atmosphere.

\section{Parameterization of sea salt emissions}

The basic mechanism for production of sea salt particles from oceans involves the breaking of ocean waves which 
entrains air into the water and generates bubbles. When these bubbles burst at the surface sea spray aerosol is produced via either fragmentation of the bubble film or ejection of a water jet as the bubble collapses (Blanchard and Woodcock, 1957). Therefore, the main physical driver of sea spray emissions is the surface wind speed which creates the ocean waves. The sea salt aerosol emissions are also regulated by sea surface temperature (Nilsson et al., 2007; Mårtensson et al., 2003) and sea ice cover (Nilsson et al., 2001b). An important aspect of sea spray emissions is the sub-micrometer size range where the highest particle numbers are produced (Mårtensson et al., 2003). This is of particular interest for climate studies because the sub-micrometer particles are important for estimating the direct aerosol effect and for the production of cloud droplets. For a comparison of sub-micrometer sea salt aerosol source parameterizations, including the Mårtensson parameterization, and their net effect in a GCM see Pierce and Adams (2006).

To simulate sea salt aerosol emissions in CAM-Oslo a modifcation of the Mårtensson parameterization was implemented. To simplify the implementation of the size distribution of the sea salt aerosol emission flux in CAM-Oslo, three log-normal modes were fitted to the Mårtensson parameterization combined with the parameteriation of Monahan et al. (1986) for particles with radii greater than $1.4 \mu \mathrm{m}$. The modal radii and geometric standard deviation $(\sigma)$ of the sea salt modes, before hydroscopic growth and aerosol processing (condensation and coagulation), are given in Table 1. Mårtensson et al. (2003) found a strong temperature dependence in the particle number emission flux which varied with particle size and which has subsequently gained support through in-situ emission measurements in tropical (Clarke et al., 2006) and temperate waters (Nilsson et al., 2007). Being a potentially important feature, this temperature dependence was approximated in the modified parameterization using a linear sea surface temperature dependence for the Aitken and accumulation modes (a1 and a2 in Table 1) and a quadratic term for the coarse mode (a3). The modal emission coefficients are given in Table 1. A linear least squares fitting routine was used to fit the modal emissions to the Mårtensson emission parameterization, which is a continuous function over the particle radius size range $10 \mathrm{~nm}-$ $1.4 \mu \mathrm{m}$. In addition, the integrated particle number emissions from the modal approximation were forced to match the number emissions from the Mårtensson parameterization over the particle radius sub-ranges: $10-72.5 \mathrm{~nm}, 72.5-$ $209.5 \mathrm{~nm}$ and $209.5 \mathrm{~nm}-1.4 \mu \mathrm{m}$ (see Mårtensson et al., 2003), ensuring that the integrated particle number flux from the modal approximation and the Mårtensson parameterization are equal.

Particle emission fluxes in each sea salt aerosol mode within the model are the product of the modal emission terms (introduced above) and the whitecap fraction within the model gridbox, given by:
Table 1. Modal radii $(r)$ and geometric standard deviations $(\sigma)$ for the three log-normal sea salt modes employed in CAM-Oslo. The three coefficients $\left(c_{2}, c_{1}\right.$ and $\left.c_{0}\right)$ describe the dependence of the modal number emission flux as a function of the sea surface temperature: $<$ flux $>_{i}=W\left(c_{2} \times \mathrm{sst}^{2}+c_{1} \times \mathrm{sst}+c_{0}\right)$, where sst is the sea surface temperature and $W$ is the whitecap area (see Mårtensson et al., 2003).

\begin{tabular}{cccccr}
\hline Mode label & $r(\mathrm{~nm})$ & $\sigma$ & $c_{2}$ & $c_{1}$ & \multicolumn{1}{c}{$c_{0}$} \\
\hline a1 & 22 & 1.59 & 0.0 & $-3.4 \mathrm{e}+06$ & $1.1 \mathrm{e}+09$ \\
$\mathrm{a} 2$ & 130 & 1.59 & 0.0 & $1.3 \mathrm{e}+05$ & $-1.3 \mathrm{e}+07$ \\
$\mathrm{a} 3$ & 740 & 2.00 & $2.1 \mathrm{e}+03$ & $-9.6 \mathrm{e}+05$ & $1.1 \mathrm{e}+08$ \\
\hline
\end{tabular}

$W=3.84 \times 10^{-4} U_{10}^{3.41}$.

$W$ is the whitecap fraction (in percent) and $U_{10}$ is the $10 \mathrm{~m}$ horizontal wind speed (Monahan and Muircheartaigh, 1980). The whitecap cover and consequently the sea salt aerosol emissions are strongly dependent on the $U_{10}$. For example a $23 \%$ increase in $U_{10}$ leads to a doubling of the whitecap area and sea spray emission.

Nilsson et al. (2001b) showed that over the central Arctic sea ice, with 10-20\% open water in leads between ice floes, the local sea spray emissions were a factor 10 smaller than those over open sea. Averaged over the ice covered areas, the emissions would be a factor $\sim 100$ smaller. This is an effect of the limited fetch, which require much higher wind speeds to create breaking waves. There are to our knowledge no studies of sea spray emissions in the marginal ice edge zone or other zones with a broken ice cover from 90-30\% coverage. Considering the coarse spatial resolution of a GCM, we have chosen to simply scale the sea spray emissions linearly with ice fraction.

Comparisons of the size resolved flux calculated using the full Mårtensson source model and the modal approximation used in CAM-Oslo for a range of sea surface temperatures is shown in Fig. 2. The modal approximation reproduces the general temperature dependence of the size resolved distribution but there are significant departures from the Mårtensson function over some particle size ranges. Most obviously, the modal function significantly underestimates emissions over the size range from approximately 60 to $150 \mathrm{~nm}$ at all temperatures. This may be important because this size range is typically important in determining the cloud droplet number concentration (CDNC). Improved fits can be obtained by varying the modal radii and geometric standard deviations, but as this is a first estimate of the impact of the sea ice/aerosol feedback it was decided to retain the values listed in Table 1 for consistency with previous AeroCom studies (Dentener et al., 2006). Subsequent investigations are planned to evaluate more fully the optimal modal approximation to the Marrtensson et al. (2003) emission parameterization. 

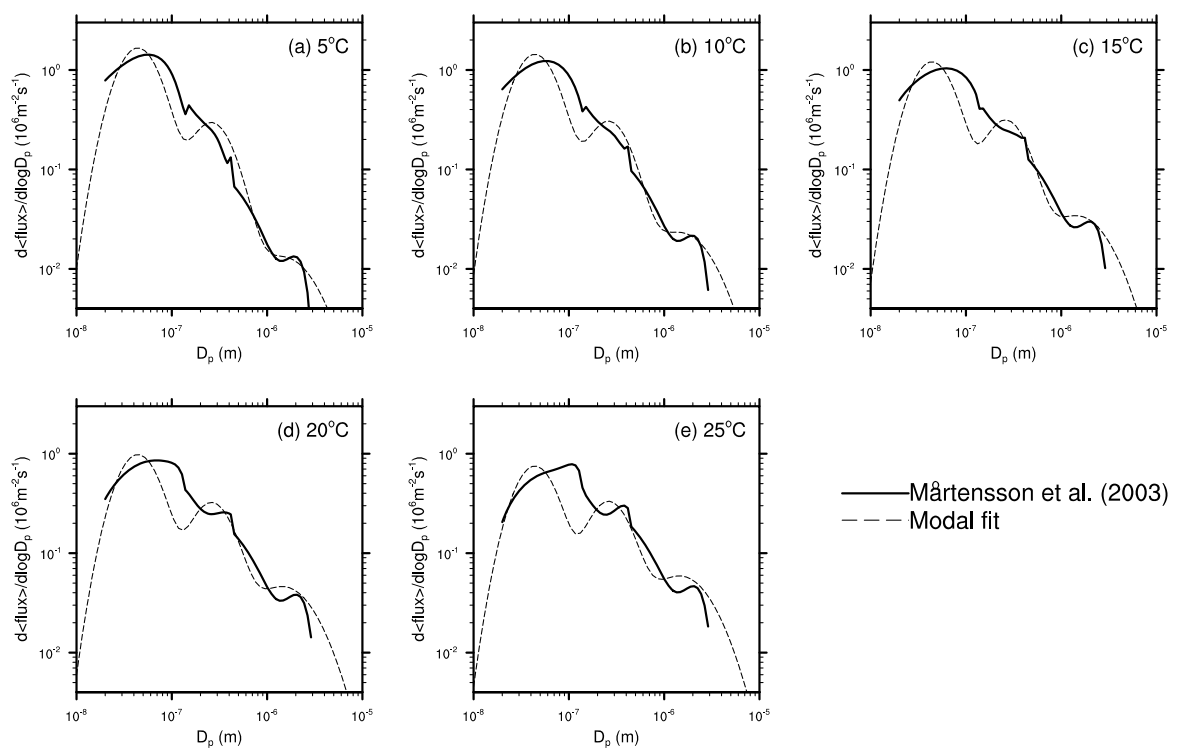

-- Modal fit

Fig. 2. Comparison of the temperature dependence of the size resolve sea salt aerosol flux from Mårtensson et al. (2003) (solid line) with the modal approximation used in CAM-Oslo (dashed line). Note: in all cases $U_{10}$ was assumed to be $9 \mathrm{~ms}^{-1}$.

\section{Model simulations}

Four model simulations were completed for this study. Wellmixed greenhouse gas concentrations were fixed at values representative of the year 2000 for all model simulations.

- Control simulation, denonted CTL (CAM3: 2000 sea ice, aerosol module: 2000 sea ice). A 6 yr integration forced by an annually repeating sea surface temperature (SST) and sea ice fraction climatology (hereafter denoted as the 2000 climatology) obtained from the data set of Hurrell et al. (2008). This data set is a blend of the observationally constrained Hadley Centre sea ice and SST data set version 1 (HadISST1) and version 2 of the National Oceanic and Atmospheric Administration (NOAA) weekly optimal interpolation (IO) SST analysis.

- Perturbation simulation 1, denoted P1 (CAM3: 2100 sea ice, aerosol module: 2000 sea ice). Similar to the CTL simulation but with a Northern Hemisphere sea ice climatology representative of the late 21 st century (hereafter denoted as the 2100 climatology) in place of the 2000 sea ice climatology. The sea salt aerosol emissions remain constrained by the same 2000 sea ice climatology as used in the CTL simulation. Even so, the sea salt aerosol emissions may in any case be slightly different due to differences in $U_{10}$. This simulation will show how the CAM3 model meteorology responds to changes in Northern Hemisphere sea ice extent. Within the aerosol module the sea ice extent is the same as the CTL simulation. Even so, the sea salt aerosol emissions may in any case be slightly different due to differences in $U_{10}$. The 2100 sea ice climatology was calculated from a three member ensemble of twenty first century CCSM3 simulations under the Special Report on Emissions Scenarios (SRES) A1B greenhouse gas forcing scenario. Arctic sea ice extent from the CCSM3 model are compared with other AR4 climate models and measurements in Stroeve et al. (2007).

- Perturbation simulation 2, denoted P2 (CAM3: 2100 sea ice, aerosol module: 2100 sea ice). The same as P1 with the exception of the sea salt emissions are constrained by the 2100 sea ice climatology. All the boundary conditions in the CAM3 climate model for this simulation are the same as the P1 simulation. Since the aerosol module is run off-line from the climate model, the meteorological fields including the cloud fraction and liquid water path, are identical to the P1 fields. Results from this simulation along with CTL and P1 results can be used to contrast the effects of surface albedo and emission changes on the aerosol radiative forcing (see Fig. 1).

- Perturbation simulation 3, denoted P3 (CAM3: 2100 sea ice, aerosol module: 2100 sea ice and 2100 SST). The same as P2 with the exception of the sea surface temperatures which were also taken from the 2100 CCSM3 climatology (applied both in the CAM3 and aerosol module). The response of sea spray emissions to changes in both ice cover and sea surface temperature can then be examined based on this simulation (see Fig. 1). 
Table 2. Matrix of CAM-Oslo simulations: 2000 represents the HadISST 1980-2000 climatology, 2100 represents the 2095-2100 climatology of CCSM3 model simulations.

\begin{tabular}{lccc}
\hline & CAM3: sea ice & SST & aerosol module: sea ice \\
\hline CTL & 2000 & 2000 & 2000 \\
P1 & 2100 & 2000 & 2000 \\
P2 & 2100 & 2000 & 2100 \\
P3 & 2100 & 2100 & 2100 \\
\hline
\end{tabular}

Table 2 depicts the choice of sea ice and sea surface temperature climatologies used in the four model simulations. Output from the last five years of each simulation was used in the subsequent analysis.

Seasonal (summer and winter) 2000 and 2100 sea ice fractions used in the model simulations are shown in Fig. 3. There are obvious reductions in Arctic sea ice extent in the 2100 data compared to the 2000 climatology, in particular the 2100 climatology is practically ice free in summer (JJA). This means that multi-year (perennial) sea ice no longer forms and all winter sea ice is reformed every new winter season throughout the Arctic. Figure 4 compares the corresponding sea surface temperature fields used in the model. Consistent with the sea ice fractions in Fig. 3, the 2100 Arctic sea surface temperatures are significantly higher than the 2000 climatology (see also Fig. 5).

The emissions of non-sea salt aerosols (sulphate, particulate organic matter, black carbon and mineral dust) and gaseous DMS and $\mathrm{SO}_{2}$ are prescribed using the data-base discussed in Dentener et al. (2006) and were left unchanged through all the model simulations. The dimethyl sulphide DMS cycle in the Arctic is dependent on the sea ice extent (Gabric et al., 2005). Even so, it is uncertain how Arctic DMS emissions will change in the future because they also depend on sea surface temperatures and ecosystem dynamics (Carslaw et al., 2010). For this reason we chose not to alter DMS emissions in our simulations. Similarly, we chose to leave the anthropogenic aerosol emissions fixed in all the model simulations to simplify the interpretation of the results, even though it is anticipated that the strength and spatial distribution of these emissions will significantly change in the future. This approach has drawbacks but does have the advantage of making the simulations directly comparable so that the effect of the specific feedback paths can be isolated and quantified.

\section{Results and discussion}

\subsection{Atmospheric response to changes in Arctic sea ice}

To better understand the changes in emissions and concentration of sea salt discussed in the following sections we consider here the fields that determine the sea salt emissions in the model and the response in the planetary boundary layer to changes in the prescribed boundary conditions. The dominant physical parameters that determine the strength of sea salt emissions are sea ice cover, surface wind speed and the sea surface temperature (Nilsson et al., 2001b; Mårtensson et al., 2003). Figure 5 compares the total area of open (ice free) ocean, the mean SST and $U_{10}$ averaged over ocean grid points between 70 and $90^{\circ} \mathrm{N}$ (the larger Arctic region) as well as between 80 and $90^{\circ} \mathrm{N}$ (roughly the area with multi-year sea ice in the current climate). Here we define ocean grid points as being all model grid points that are not land points (i.e. including both open ocean and ice covered ocean). As indicated in Fig. 3 there is a large increase in the area of open ocean in the 2100 climatology compared to the 2000 climatology, including almost ice free conditions from July to October, when only the Canadian Arctic and waters north of Greenland remain ice covered. In line with the increase in open ocean the averaged SST shows a relatively uniform increase of between 3 and $4{ }^{\circ} \mathrm{C}$ for the 2100 climatology compared to the 2000 climatology when averaged between 70 and $90^{\circ} \mathrm{N}$. The $2100 \mathrm{SST}$ increase affects the direct emission of sea salt through the temperature dependence in the source parameterization but there are also indirect consequences to the aerosol life-cycles caused by changes in relative humidity and clouds/fog as discussed below.

The $U_{10}$ from the model compares reasonably well with ECMWF ERA-Interim (Dee and Uppala, 2009) reanalysis data (Fig. 5e and f), but the modeled wind speed is somewhat higher, particularly in winter which results in a more pronounced annual cycle. In practice, the ECMWF ERAInterim reanalysis for the central Arctic is based on a very sparse observational network however a similar annual cycle was observed during the Surface Heat Budget of the Arctic Ocean (SHEBA) expedition (Persson et al., 2002) and the average summer wind speed is in agreement with data from the IAOE-91 and IAOE-96 campaigns over the Arctic pack ice (Nilsson and Barr, 2001; Nilsson, 1996). Increasing the area of ice free ocean in the model does not strongly influence the average $U_{10}$ over the Arctic polar cap. In the summer the wind speed changes very little and in December there is a slight decrease. Note also that the aerosol module in the model is decoupled to the modeled meteorology and so the P1 and P2 $U_{10}$ (as with all other meteorological fields) are identical. Although not shown here, changes in the sea ice extent in the P1 and P2 simulations relative to CTL simulation results in weaker surface winds south and east of Greenland, consistent with the southward-shifted and more zonal north Atlantic storm track simulated by Magnusdottir et al. (2004) using the CCM3 model. Nilsson et al. (2001b) showed that for moderate wind speeds, a decline in sea ice similar to that prescribed in the model simulations can increase sea spray emissions by a factor of approximately 2. Therefore we expect that the changes in sea salt aerosol emissions between the model simulations are mainly due to changes in sea ice extent, with a contribution from the change in SST in the P3 simulation (refer to Fig. 1). 

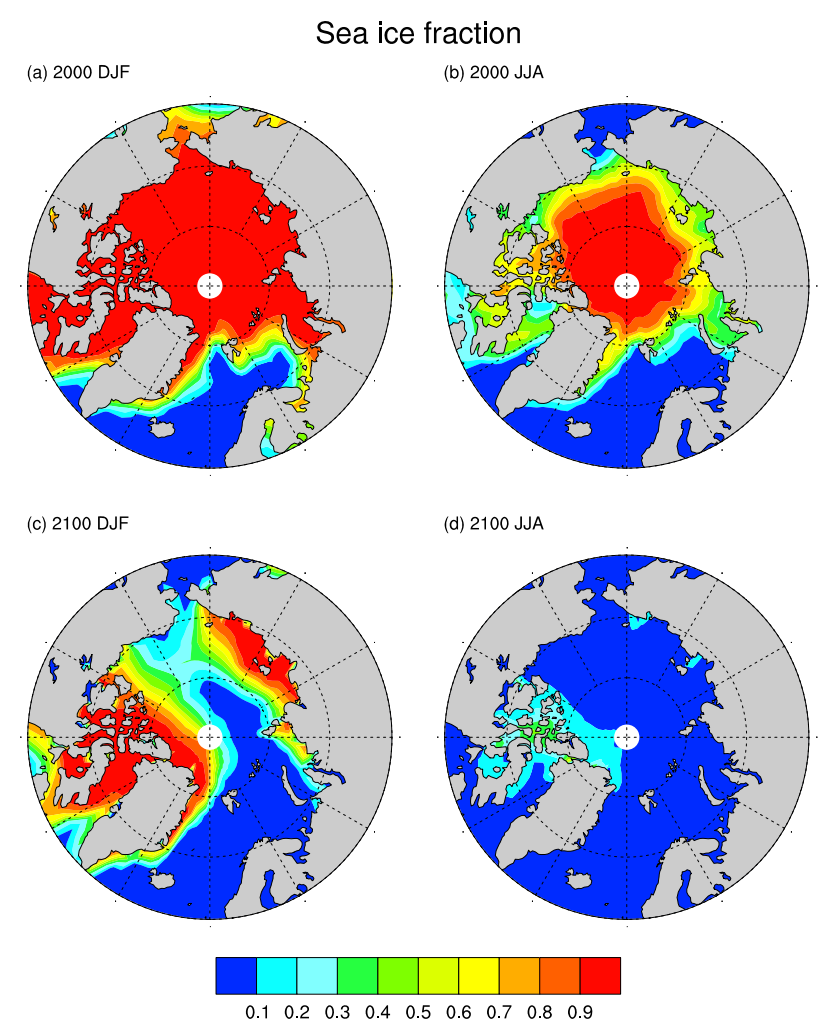

Fig. 3. Winter (DJF) and summer (JJA) sea ice fraction prescribed in the model: 2000 climatology from Hurrell et al. (2008), 2100 climatology derived using an average of three ensemble CCSM3 model simulations based on the A1B SRES scenario.

Unlike $U_{10}$ the turbulent surface latent and sensible heat fluxes, the planetary boundary layer height and low cloud fraction show clear differences between the different model integrations (Fig. 6). The annual average cycle of the latent turbulent heat flux of the CTL simulation agree reasonably well in shape and magnitude with the data from the SHEBA experiment (Persson et al., 2002) (not shown here). The averaged sensible turbulent heat flux was close to zero in the summer months of the SHEBA experiment. The CTL experiment shows a small negative average sensible heat flux in the summer, while the winter results agree fairly well. Differences between the modeled turbulent heat fluxes are caused by changes in the sea ice cover because the ice insulates against turbulent exchange between the ocean and the atmosphere. The increased area of open ocean in the perturbation simulations allows for increases in heat exchange. This increase in turbulent heat flux shows the largest magnitudes (opposite in sign) in the winter when the temperature difference between the ocean and the overlying atmosphere is largest while the turbulent heat fluxes over the multi-year ice $\left(80-90^{\circ} \mathrm{N}\right)$ of the CTL simulation are close to zero in winter. The changes in the turbulent surface heat exchange in response to changes in sea ice fraction are in agreement with the model study by Deser et al. (2010).
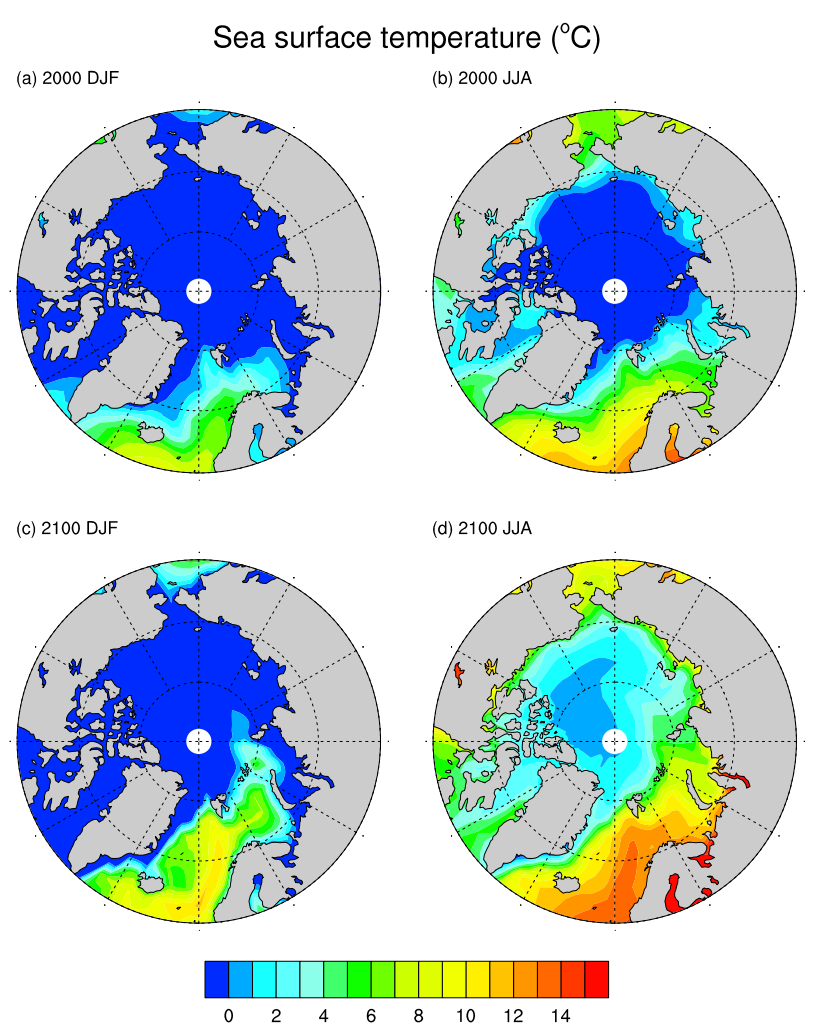

Fig. 4. Winter (DJF) and summer (JJA) sea surface temperature prescribed in the model: 2000 climatology from Hurrell et al. (2008), 2100 climatology derived using an average of three ensemble CCSM3 model simulations based on the A1B SRES scenario.

The increased turbulent heat flux in turn deepens the boundary layer height (Fig. 6c and d) and increases the low level cloud fraction (Fig. 6e and f). An adjustment of the parameterization of fractional cloudiness was applied in the present version of CAM-Oslo to improve the simulation of low-level cloudiness in the Arctic. The adjusted parameterization includes a representation of the direct scavenging of water vapour in very cold air (see Seland et al., 2008). The agreement between the low level cloud fraction from the model and ECMWF ERA-Interim is generally poor, which reduces the confidence in the model's estimate of cloud radiative forcing (discussed in Sect. 5.2.2) however problems have also been identified in reanalysis estimates of Arctic cloudiness (Walsh et al., 2009). A comparison with local observations during the year-long SHEBA experiment show a minima in low cloud fraction in winter (down to 0.4) and maxima during the summer months ( 0.8 or larger) (Intrieri et al., 2002) which suggests that the CTL cloud cover may be more realistic than the ECMWF ERA-Interim re-analysis. The perturbation simulations show an increase in low cloud fraction throughout the year relative to the CTL simulation which is most pronounced in the winter. Despite this there is still a maxima in cloudiness in the summer, but the amplitude in the annual cycle is reduced. 
$70^{\circ} \mathrm{N}-90^{\circ} \mathrm{N}$
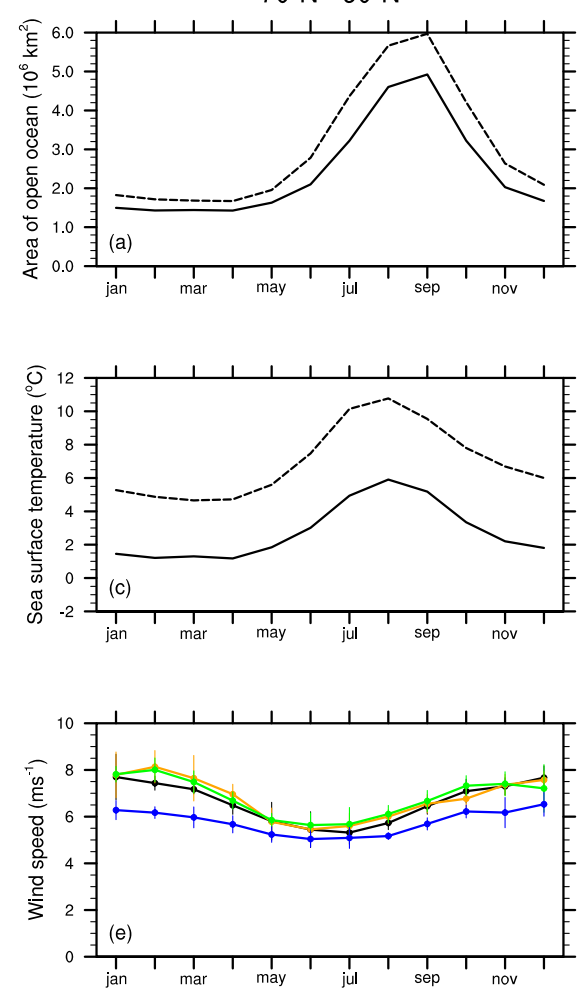

$80^{\circ} \mathrm{N}-90^{\circ} \mathrm{N}$
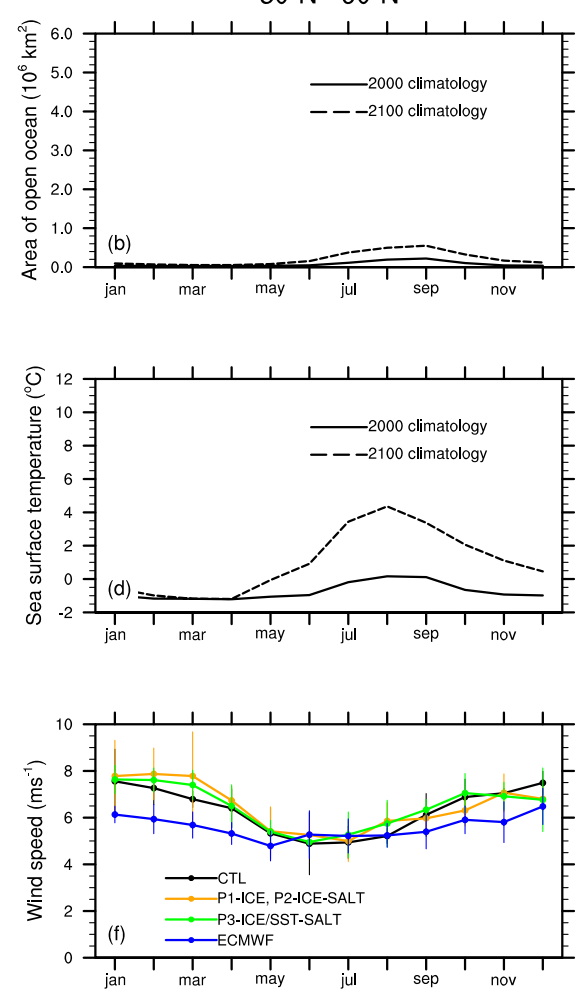

Fig. 5. Fields determining the emission of sea salt aerosol in the model. (a), (b) prescribed total open ocean area, (c), (d) prescribed sea surface temperature and (e), (f) monthly average $U_{10}\left(70\right.$ to $90^{\circ} \mathrm{N}$ (left hand panels) and 80 to $90^{\circ} \mathrm{N}$ (right hand panels)). Only grid points over ocean are included in the averaging of the $U_{10}$ which are taken over the final five years of the model simulations. Blue lines in (e) and (f) are monthly mean $U_{10}(2000-2005)$ from the ECMWF ERA-Interim data set. Vertical lines indicate the two standard deviations corresponding to the monthly means.

\subsubsection{Sea salt aerosol emissions}

Figure 7 compares the area-averaged (ocean grid points only) seasonal cycle of sea salt aerosol emission flux from the CAM-Oslo model simulations. Sea salt number emission flux $\left(\mathrm{m}^{-2} \mathrm{~s}^{-1}\right)$ for the three aerosol modes are shown separately. Note the change of units of the $y$-axes in the figures which reflects the fact that the number flux is dominated by sub-micron particles.

The modeled seasonal cycle in sea salt emissions is determined through a combination of seasonal cycles in $U_{10}$, SST and sea ice extent. The emission peak in early winter demonstrates how the $U_{10}$ has a strong influence on the magnitude of emissions and the shape of the seasonal cycle (compare with winter maxima and summer minima in Fig. 5). The sea ice changes strongly influences the sea salt flux in the model, shown in Fig. 7. The CTL and P1 sea salt emissions are almost identical and are significantly lower than the P2 and P3 emissions with practically no flux between 80 and $90^{\circ} \mathrm{N}$ where there is a limited area of open ocean. The emissions from the P2 and the P3 simulations for the Aitken (a1) and accumulation (a2) modes are similar. The P3 fluxes being slightly lower in late winter although they agree within the uncertainty ranges given by the interannual variability. The P3 coarse-mode emissions are much greater than the other model simulations (Fig. 7e and f), although the sea salt number flux is small compared to the a1 and a2 modes. Annual average and JJA results, including both the total sea salt number and mass emission fluxes are also given in Tables 3 and 4 . The annually averaged increase in number flux for P3 compared to the CTL simulation attributed to a combination of changes in sea ice cover and SST is $85.6 \times 10^{6} \mathrm{~m}^{-2} \mathrm{~s}^{-1}$ for $70-90^{\circ} \mathrm{N}$ which is an increase by a factor of three (Table 3 ). The corresponding sea salt mass emission flux increases by a factor of 3.5.

The summer and winter seasonal patterns of the changes in sea salt emissions, for the perturbation simulations relative to the CTL simulation, are shown in Fig. 8. As expected, the differences between the P1 and the CTL simulations are small and the increased emissions for the $\mathrm{P} 2$ and $\mathrm{P} 3$ cases are correlated with the ice loss shown in Fig. 3. The decreases in sea salt emissions, relative to the CTL simulation southeast of Greenland in the P1, P2 and P3 results are associated with decreases in surface wind speed caused by the changes in the 

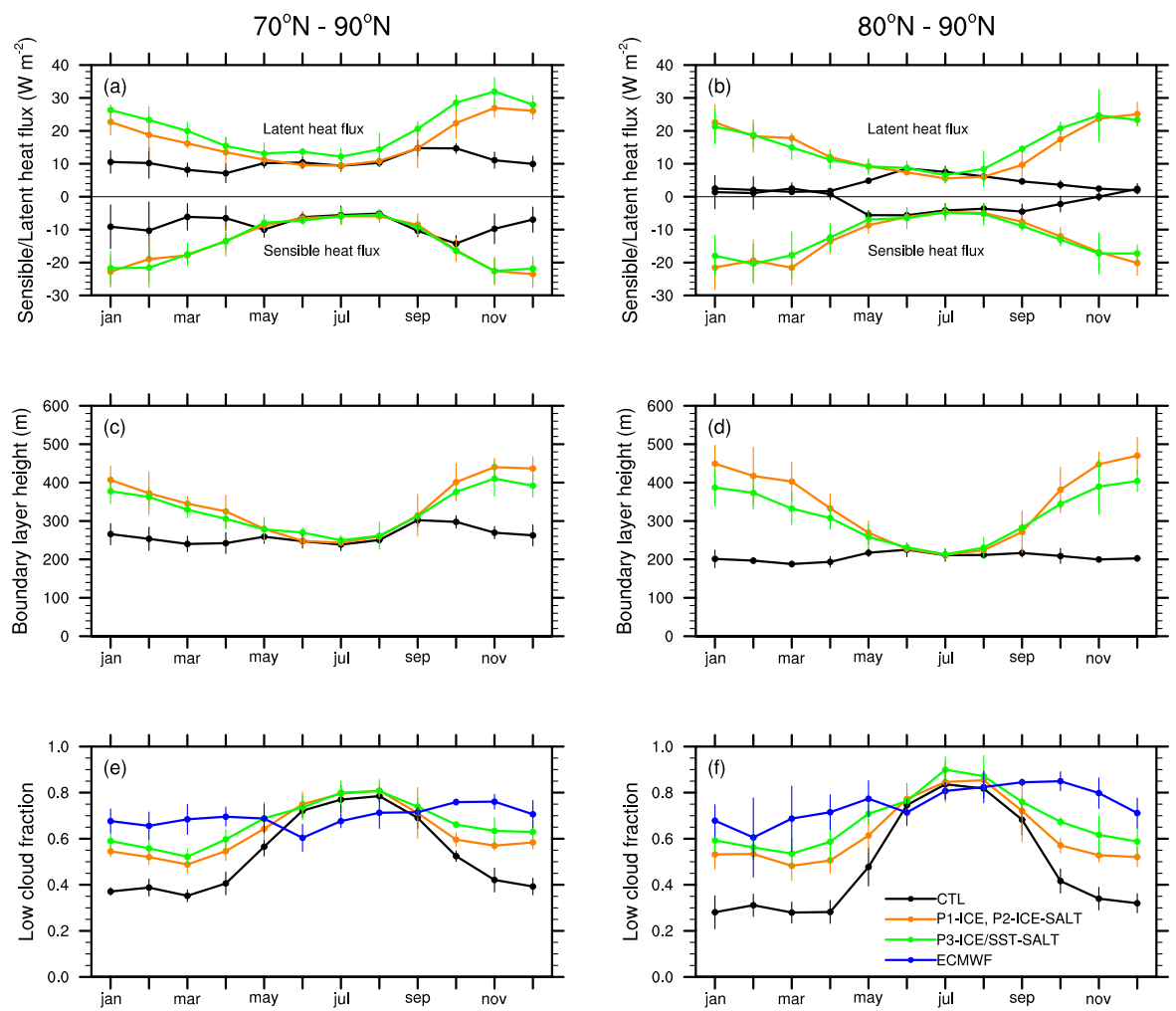

Fig. 6. Modeled boundary layer response to changes in Arctic sea ice. (a), (b) average (ocean grid points only) surface latent and sensible heat flux, (c), (d) boundary layer height and (e), (f) low cloud fraction. Values are averages over the final five years of the model integrations. Vertical lines indicate two standard deviations corresponding to the monthly means.

winter storm tracks as discussed above. Differences between the P2 and P3 wintertime patterns can be distinguished, most clearly over the Norwegian Sea and Barents Sea which are due to the different SST climatologies used. The higher temperatures in the $\mathrm{P} 3$ simulation compared to the $\mathrm{P} 2$ simulation reduces the total sea salt number emissions in these regions and cancels the increase caused by other factors.

\subsubsection{Sea salt aerosol concentration and aerosol optical depth}

Figure 9 shows the influence of changes in emissions on the modeled sea salt concentrations, the integrated column of sea salt and CDNC and the aerosol residence time. The aerosol residence time is defined here as the total sea salt aerosol burden $(\mathrm{kg})$ divided by the sum of the dry and wet deposition sinks in $\mathrm{kg} \mathrm{m}^{-2} \mathrm{~s}^{-1}$ (area-averaged over ocean grid points only). As expected from the emission results (Fig. 7) the boundary layer concentration and vertically integrated column of sea salt is higher in the P2 and P3 simulations compared to the CTL and P1 simulations. As mentioned above, sea salt mass flux is dominated by the coarse mode whereas the number emissions are dominated by the Aitken and accumulation modes. Emission of larger particles is favoured by increasing temperatures which helps explains why $\mathrm{P} 3$ has the highest boundary layer mass concentrations (Fig. 9a and b), particularly during the warmer period, while the difference is smaller in the late winter-spring. The column integrated sea salt aerosol number are highest for P2 (Fig. 9c and d). The P3 column integrated aerosol number is lower than the $\mathrm{P} 2$ case over the winter and early spring period due to a combination of slightly lower emission fluxes for the a1 and a2 modes in response to higher SSTs (Fig. 7a-d) and shorter sea salt aerosol residence times for the $\mathrm{P} 3$ case.

The averaged vertical column of CDNC peaks in summer in accordance with the cloud fraction (see Fig. 6e and f). The CDNC vertical column from the P3 simulation is considerably higher than the other model simulations, due to the higher concentration of coarse mode particles (a3) in this simulation (in turn due to higher SSTs) which activate to cloud droplets at lower supersaturations than the sub-micron particles. In the cloud condensation nucleii lookup tables used in the model, the activation of aerosols to form cloud droplets is estimated using the Köhler equation and is therefore dependent on the particle size distribution.

In general, the average sea salt aerosol residence times decrease in the order CTL, P1, P2, P3 and the largest differences occur in late winter. Both the wet and dry deposition 
Table 3. CAM-Oslo results averaged between 70 and $90^{\circ} \mathrm{N}$. The averaging includes all grid points (land and ocean) and covers the final five years of the model simulations.

\begin{tabular}{|c|c|c|c|c|c|c|c|}
\hline & $\begin{array}{l}\text { SS total number } \\
\text { flux }\left(10^{6} \mathrm{~m}^{-2} \mathrm{~s}^{-1}\right)\end{array}$ & $\begin{array}{c}\text { SS total mass } \\
\text { flux }\left(\mu \mathrm{g} \mathrm{m}^{-2} \mathrm{~s}^{-1}\right)\end{array}$ & $\begin{array}{c}\text { SS integrated } \\
\text { column }\left(10^{3} \mathrm{~m}^{-2}\right)\end{array}$ & Natural AOD & Total AOD & $\begin{array}{c}\text { Aerosol direct } \\
\text { forcing }\left(\mathrm{W} \mathrm{m}^{-2}\right)\end{array}$ & $\begin{array}{c}\text { SW cloud } \\
\text { forcing }\left(\mathrm{W} \mathrm{m}^{-2}\right)\end{array}$ \\
\hline \multicolumn{8}{|c|}{ Annual average } \\
\hline CTL & 42.8 & 9.0 & 39.6 & 0.030 & 0.090 & -0.085 & -22.0 \\
\hline $\mathrm{P} 1$ & 55.3 & 10.4 & 38.3 & 0.029 & 0.088 & -0.126 & -35.8 \\
\hline $\mathrm{P} 2$ & 141.0 & 14.0 & 62.7 & 0.042 & 0.099 & -0.163 & -36.1 \\
\hline P3 & 128.4 & 31.7 & 49.3 & 0.037 & 0.085 & -0.142 & -38.2 \\
\hline \multicolumn{8}{|c|}{ JJA average } \\
\hline CTL & 27.4 & 7.1 & 13.7 & 0.014 & 0.082 & -0.085 & -63.7 \\
\hline $\mathrm{P} 1$ & 39.3 & 8.5 & 15.3 & 0.015 & 0.085 & -0.184 & -103.1 \\
\hline $\mathrm{P} 2$ & 92.3 & 11.5 & 29.4 & 0.023 & 0.092 & -0.260 & -104.1 \\
\hline P3 & 90.4 & 30.5 & 26.0 & 0.023 & 0.086 & -0.252 & -107.7 \\
\hline
\end{tabular}

Table 4. CAM-Oslo results averaged between 80 and $90^{\circ} \mathrm{N}$. The averaging includes ocean grid points only and covers the final five years of the model simulations.

\begin{tabular}{|c|c|c|c|c|c|c|c|}
\hline & $\begin{array}{l}\text { SS total number } \\
\text { flux }\left(10^{6} \mathrm{~m}^{-2} \mathrm{~s}^{-1}\right)\end{array}$ & $\begin{array}{c}\text { SS total mass } \\
\text { flux }\left(\mu \mathrm{g} \mathrm{m}^{-2} \mathrm{~s}^{-1}\right)\end{array}$ & $\begin{array}{c}\text { SS integrated } \\
\text { column }\left(10^{3} \mathrm{~m}^{-2}\right)\end{array}$ & Natural AOD & Total AOD & $\begin{array}{c}\text { Aerosol direct } \\
\text { forcing }\left(\mathrm{Wm}^{-2}\right)\end{array}$ & $\begin{array}{c}\text { SW cloud } \\
\text { forcing }\left(\mathrm{Wm}^{-2}\right)\end{array}$ \\
\hline \multicolumn{8}{|c|}{ Annual average } \\
\hline CTL & 3.5 & 0.4 & 36.8 & 0.026 & 0.081 & -0.046 & -10.9 \\
\hline P1 & 10.3 & 0.8 & 34.4 & 0.025 & 0.078 & -0.114 & -35.6 \\
\hline $\mathrm{P} 2$ & 137.2 & 4.7 & 67.9 & 0.041 & 0.092 & -0.163 & -36.1 \\
\hline P3 & 124.8 & 18.0 & 54.5 & 0.039 & 0.082 & -0.132 & -38.7 \\
\hline \multicolumn{8}{|c|}{ JJA average } \\
\hline CTL & 2.6 & 0.3 & 10.4 & 0.011 & 0.070 & 0.012 & -34.4 \\
\hline P1 & 10.4 & 0.8 & 12.0 & 0.012 & 0.071 & -0.156 & -110.8 \\
\hline $\mathrm{P} 2$ & 92.7 & 3.7 & 33.0 & 0.024 & 0.082 & -0.269 & -112.4 \\
\hline P3 & 83.6 & 17.3 & 29.4 & 0.024 & 0.080 & -0.221 & -118.1 \\
\hline
\end{tabular}

sinks contribute significantly to the reduction in the residence times (not shown) and are related to the particle size (higher deposition rates for larger particles) which explains why the P3 simulation has the shortest residence times. The wet deposition is also affected by the cloud fraction. During the Arctic-Ocean-Expedition 1996 in July-August Nilsson and Rannik (2001) found the overall aerosol number residence time with regard to dry deposition over Arctic sea ice to be 4.6 days, while the Aitken mode (corresponding roughly to a1) had a residence time of 3.5 days. The over-all value is strongly influenced by the ultrafine mode (1.3 days), but suggests that the accumulation mode (a2) would have a residence time longer than 4.6 days. Nilsson and Leck (2002) estimated the sub-micrometer sulfur mass aerosol (dominated by the accumulation mode) residence time to range from less than one day near the ice edge (dominated by wet deposition) to more than one week well into the ice (International Arctic Ocean Expedition 1991, August to September 1991). While this was not for sea salt, sulfate aerosols and sea salt are among the more hygroscopic aerosol components, so their wet deposition efficiency should be roughly similar. These numbers support the summer-minima in residence time in Fig. 9. For the winter we are not aware of any similar studies, but it is generally assumed that in the late winter to early spring the aerosol residence times are high in the Arctic, which is one reason behind the Arctic Haze phenomena (Shaw, 1995). It therefore appears as if the residence times in our experiments may be reasonable.

Aerosol radiative effects within the model can be separated into natural and anthropogenic components. The natural aerosol component of the total aerosol burden includes sea salt and mineral dust. Note also that in the radiative calculations the natural aerosols are treated as aged particles and are therefore internally mixed including sulphate and organic material. Figure 10a and $\mathrm{b}$ show the relative contribution to the total AOD of the five components of the aerosol in the model (black carbon, particulate organic matter, sulphate, mineral dust and sea salt) for the CTL simulation. The relative contributions of the components in the other simulations are similar and not shown here. As expected from Fig. 9, the sea salt AOD shows a maximum in winter and is the dominant component of the natural aerosol from 

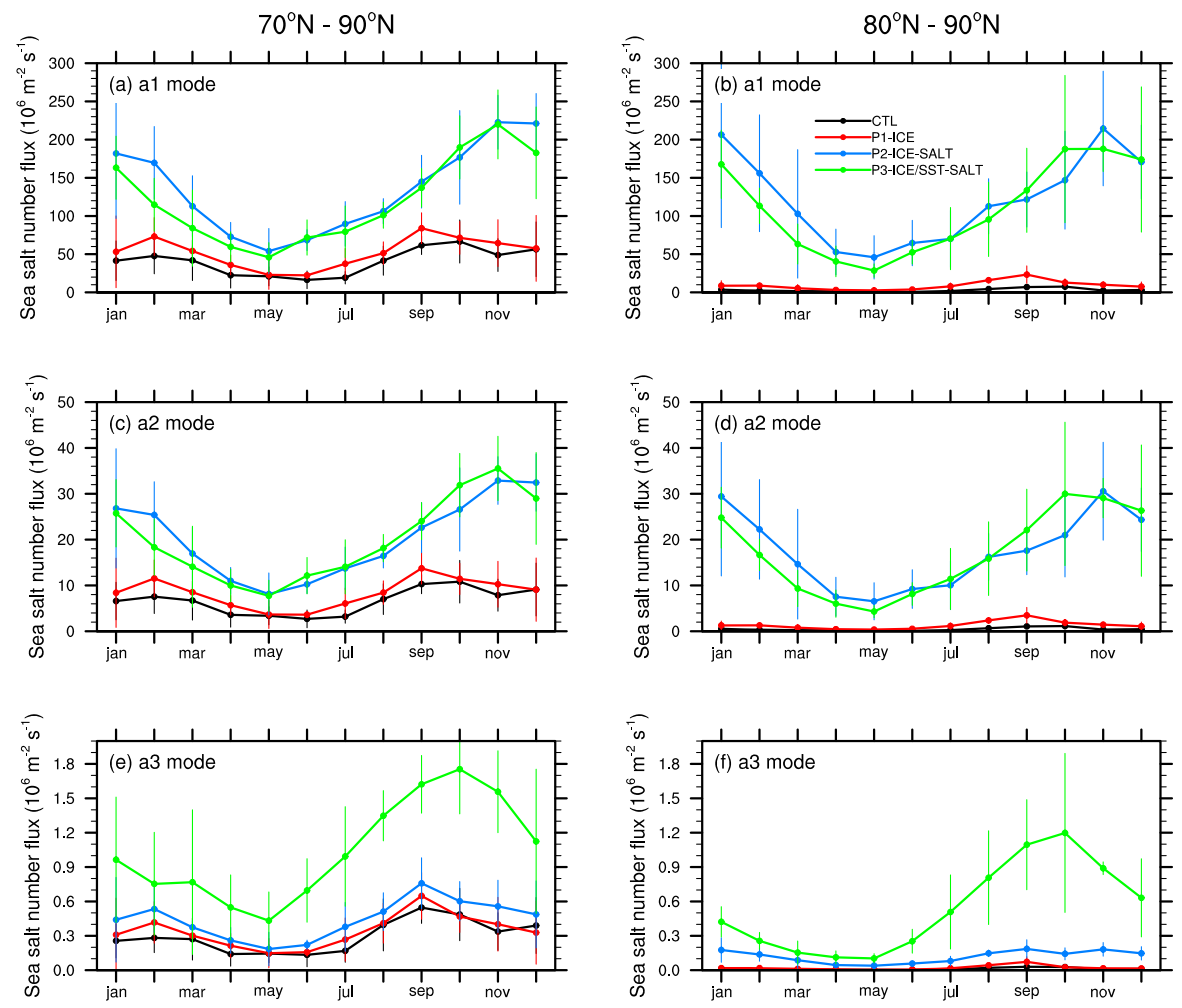

Fig. 7. Average (ocean grid points only) Arctic sea salt surface emission fluxes $\left(10^{6} \mathrm{~m}^{-2} \mathrm{~s}^{-1}\right)$ for the three sea salt aerosol modes used CAM-Oslo (see Table 1). Values are averages over the final five years of the model integrations. Vertical lines indicate the two standard deviations corresponding to the monthly means.

September until April. Black carbon and mineral dust contribute relatively little to the total AOD over the Arctic. Sulphate contributes approximately 0.03 to the simulated total AOD, reasonably uniformly throughout the year. The particulate organic matter contribution shows a maximum in summer, which is attributed to long range transport of anthropogenic aerosols from lower latitudes since no primary marine organic sources are included in the model. The natural and total AOD at $550 \mathrm{~nm}$ for all model simulations are compared in Fig. 10c and d. The seasonal cycles and differences between the model results of the natural AOD are similar to the column integrated sea salt number shown in Fig. 9c and d. The P2 simulation produces on the whole, the highest natural AOD and the $\mathrm{P} 3$ simulation gives similar results to the P2 case over the summer and autumn period but lower values in winter.

The spatial pattern of changes in the natural AOD for the $\mathrm{P} 1, \mathrm{P} 2$ and P3 simulations relative to the CTL simulation are shown in Fig. 11. The changes in the AOD fields in Fig. 11 show some of the signatures seen in the emission fields (Fig. 8) but are also influenced by changes in dry and wet deposition and transport between the different perturbation simulations. Although not shown here, changes in cloud amount in winter alters the pattern of wet scavenging of aerosols which in turn alters the AOD signal relative to the emission patterns seen in 8. For example, increased wintertime cloud fraction in the P3 simulation over northern Eurasia decreases the natural AOD in this region relative to the other simulations.

\subsection{Arctic aerosol radiative forcing}

\subsubsection{Natural aerosol direct radiative forcing}

Changes in surface albedo and sea salt aerosol burden resulting from a loss of Arctic sea ice will alter the radiative balance in Arctic. The direct radiative effect of these changes is illustrated in Fig. 12 which shows the average of the top-ofthe-atmosphere (TOA) direct radiative forcing of the natural aerosol calculated using output from the CTL and perturbation simulations. The averaging in this case includes all the model grid points (land and ocean). The natural aerosols in the model is essentially non-absorbing and thus the aerosol forcing shown in Fig. 12b primarily arises from scattering of short-wave radiation.

Natural aerosol forcing estimates from the CTL simulation are generally negative with absolute values less than $0.2 \mathrm{Wm}^{-2}$. The values for May to July are positive for the $80-90^{\circ} \mathrm{N}$ average implying a warming signature from these 
JJA
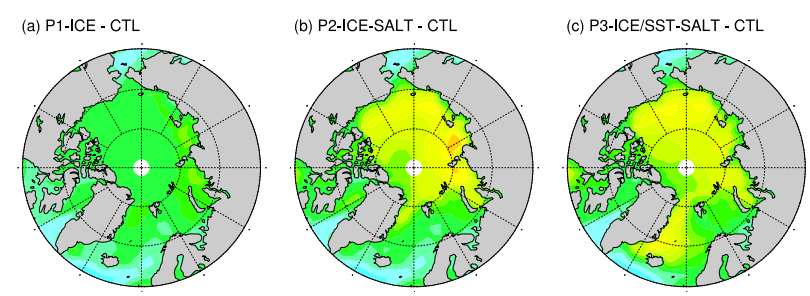

DJF
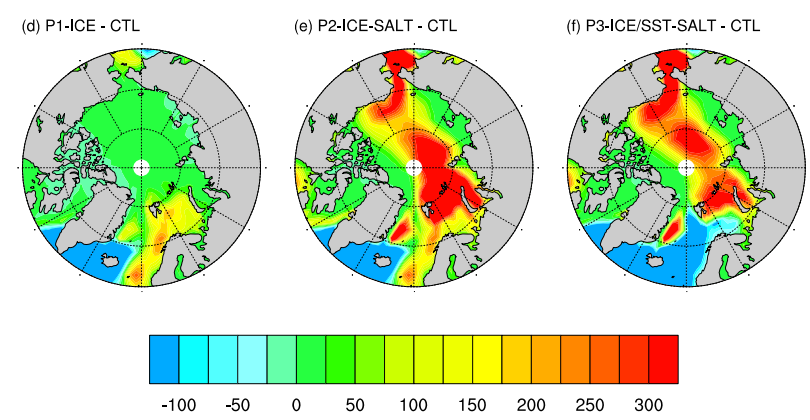

Fig. 8. Average summer (JJA) and winter (DJF) modeled difference (relative to the CTL simulation) in the total sea salt surface emission fluxes $\left(10^{6} \mathrm{~m}^{-2} \mathrm{~s}^{-1}\right)$ in response to changes in sea ice extent.

non-absorbing aerosols for this period. This effect is due to a combination of scattering aerosols overlying a high albedo (sea ice) surface and relative high solar zenith angles. Especially in spring and early summer the Arctic sea ice has a high albedo $(0.7$ to $>0.9)$ due to layers of snow lying on top of the ice, while more modest values $(0.4-0.7)$ occur later in the summer season when the surfaces are melting (Intrieri et al., 2002). Also the open water within the sea ice and melt ponds on the ice have a high surface albedo when solar zenith angles are high. Total reflection and the Fresnel law cause the water surface albedo to rapidly approach 1.0 instead of the typical 0.1 (Nilsson et al., 2001a). The factors affecting the aerosol direct radiative forcing, including the surface albedo are discussed by Hatzianastassiou et al. (2004). The seasonal cycles of the P1, P2 and P3 simulations show features that can also be discerned in the column integrated sea salt number and natural AOD. Differences between the perturbation simulations and the CTL simulation are shown in Fig. 12c and d. The difference in the natural aerosol direct forcing between the P1 and CTL simulations can primarily be attributed to the change in surface albedo since the sea salt aerosol emissions, column burdens and the natural AOD are very similar in the two simulations (see Figs. 7-11).

The increase in magnitude of the aerosol forcing in the $\mathrm{P} 2$ and P3 simulations arises due to the local increase in sea salt aerosol emissions, and is approximately $50 \%$ $\left(\sim-0.1 \mathrm{Wm}^{-2}\right)$ of the ice-albedo effect, the latter represented by the difference in aerosol forcing between the P1
Table 5. Difference matrix (in $\mathrm{Wm}^{-2}$ ) for the JJA averaged aerosol direct forcing (see Tables 3 and 4).

\begin{tabular}{lcccccc}
\hline & \multicolumn{3}{c}{70 to $90^{\circ} \mathrm{N}$} & \multicolumn{4}{c}{80 to $90^{\circ} \mathrm{N}$} \\
\hline & P1 & P2 & P3 & P1 & P2 & P3 \\
\hline CTL & -0.10 & -0.18 & -0.17 & -0.17 & -0.28 & -0.23 \\
P1 & & -0.08 & -0.07 & & -0.11 & -0.07 \\
P2 & & & 0.01 & & & 0.05 \\
\hline
\end{tabular}

and CTL simulations. The combined effect of decreasing surface albedo and increasing the sea salt aerosol burden leads to an overall aerosol direct forcing change that peaks around -0.2 to $-0.4 \mathrm{Wm}^{-2}$ in June. It is worth pointing out that the P3 simulation for the most part closer to the P1 than the P2 simulations (Fig. 12), especially for the spring which can also seen in the AOD results (Fig. 10). The likely reason for this is the decrease in the residence time for sea salt aerosol particles (see Fig. 9g and h) which in turn is dependent on the wet deposition efficiency (Sect. 5.1.2). Even though the sea ice cover was reduced from CTL to P1 and $\mathrm{P} 2$, the sea surface temperature was kept below freezing in the ice free regions. The cold ocean temperature inhibits the occurrence of warm clouds (see Fig. 9e and 9f). An increase in SST increases the amount of warm clouds thus making the scavenging process more efficient.

The differences in the JJA averaged aerosol direct forcing between the model simulations are given in Table 5, which shows a combined albedo and aerosol effect (including SST changes) of $-0.17 \mathrm{Wm}^{-2}\left(70-90^{\circ} \mathrm{N}\right)$ and $-0.23 \mathrm{Wm}^{-2}\left(80-90^{\circ} \mathrm{N}\right)$. Although not directly comparable, Winton (2006) report a global mean surface albedo feedback of $0.30 \mathrm{Wm}^{-2} \mathrm{~K}^{-1}$ derived from the output of $12 \mathrm{AR} 4$ models, with average values for the Arctic region ranging between 1 and $5 \mathrm{Wm}^{-2} \mathrm{~K}^{-1}$.

Figure 13 compares fields of the differences in TOA natural aerosol direct radiative forcing between the perturbation and control simulations for the summer. The corresponding winter results are not shown as there is practically no natural aerosol short-wave forcing during this season in the Arctic. The spatial patterns of the forcing arise due to a combination of the change in surface albedo and changes in aerosol loading (as a result of changes in emissions, transport and sinks). As expected, the P1 - CTL results shown in Fig. 13 correlates with the change in sea ice in Fig. $3 \mathrm{~b}$ and d. The P2 - CTL and P3 - CTL aerosol direct forcing differences (Fig. 13b and c respectively) result from a combination of the surface albedo change and the increase in sea salt aerosol optical depth (Fig. 11b and c).

\subsubsection{The first natural aerosol indirect effect}

Comparing the short-wave cloud forcing at the TOA from the P1 and the P2 model simulations allows us to estimate 
$70^{\circ} \mathrm{N}-90^{\circ} \mathrm{N}$
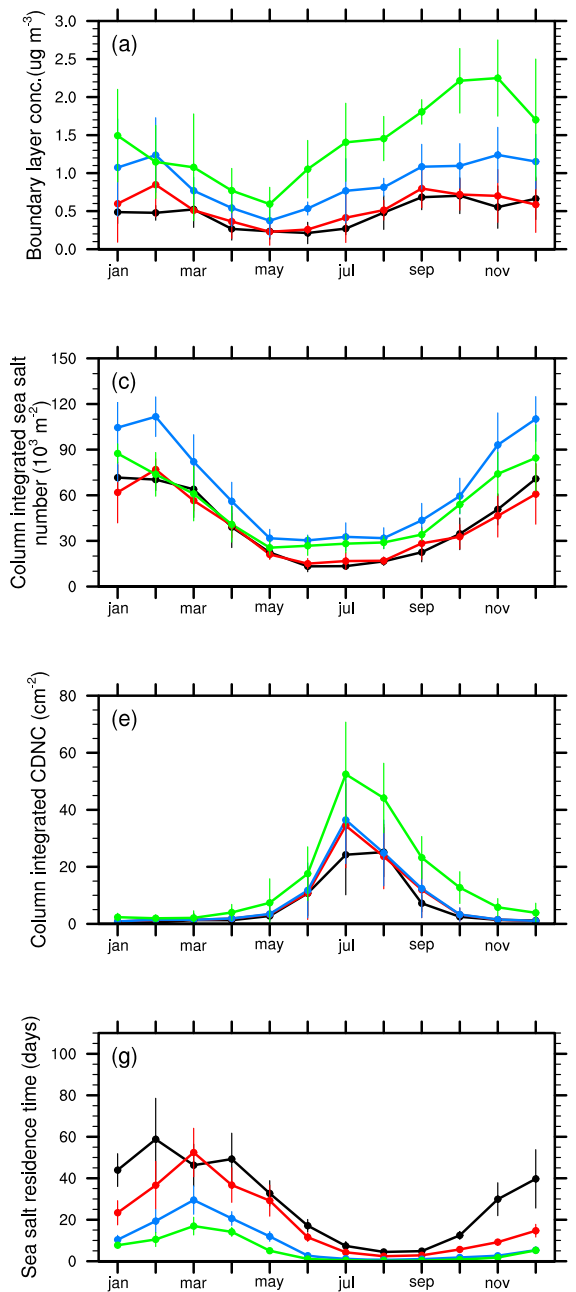

$80^{\circ} \mathrm{N}-90^{\circ} \mathrm{N}$


Fig. 9. (a), (b) Modeled Arctic sea salt boundary layer concentrations $\left(\mu \mathrm{g} \mathrm{m}{ }^{-3}\right)$, (c), (d) sea salt aerosol column burdens $\left(10^{3} \mathrm{~cm}^{-2}\right),($ e), (f) vertically integrated cloud droplet number concentration $\left(\mathrm{cm}^{-2}\right)$ and $(\mathbf{g})$, (h) sea salt aerosol residence times in days. Averages are taken over ocean grid points only for the final five years of the model integrations. Vertical lines indicate the two standard deviations corresponding to the monthly means.

the the radiative effect of the change in cloud albedo, i.e. the first aerosol indirect effect (Twomey, 1977). The P1 and the P2 model simulations use the same climate boundary conditions (Table 2) and since the aerosol module is not coupled to the climate model, any difference in short-wave cloud forcing between these two simulations can be attributed solely to changes in the simulated microphysical properties of the clouds. Comparisons between the other model simulations are complicated by changes in surface albedo, cloud fraction and liquid water paths which hamper the interpretation of any differences in short-wave cloud forcing. It is worth noting however that the there are large differences in the shortwave cloud forcing between the model simulations (Tables 3 and 4), indicating that changes in surface albedo and cloud amount strongly influences the cloud radiative forcing. In particular the P3 scenario is interesting due to the large increase in CDNC compared to $\mathrm{P} 1$ and $\mathrm{P} 2$ cases, (Fig. 9e-f) which relates to the influence of SST changes on cloud formation.

Figure 14 compares the direct and first indirect natural aerosol forcing derived from the difference between the P2 and the P1 model simulations over the polar cap. Figure 15 shows the corresponding fields of the natural aerosol direct and indirect forcing inferred from the model, averaged over the summer season. Model results suggest that the indirect effect is of the order of 10 times larger than the aerosol direct forcing, ranging between -1 and $-3 \mathrm{Wm}^{-2}$ over the summer period. The large increase in indirect aerosol forcing takes place between May and June, whilst the increase in CDNC column occurs between June and July and the CDNC remain 

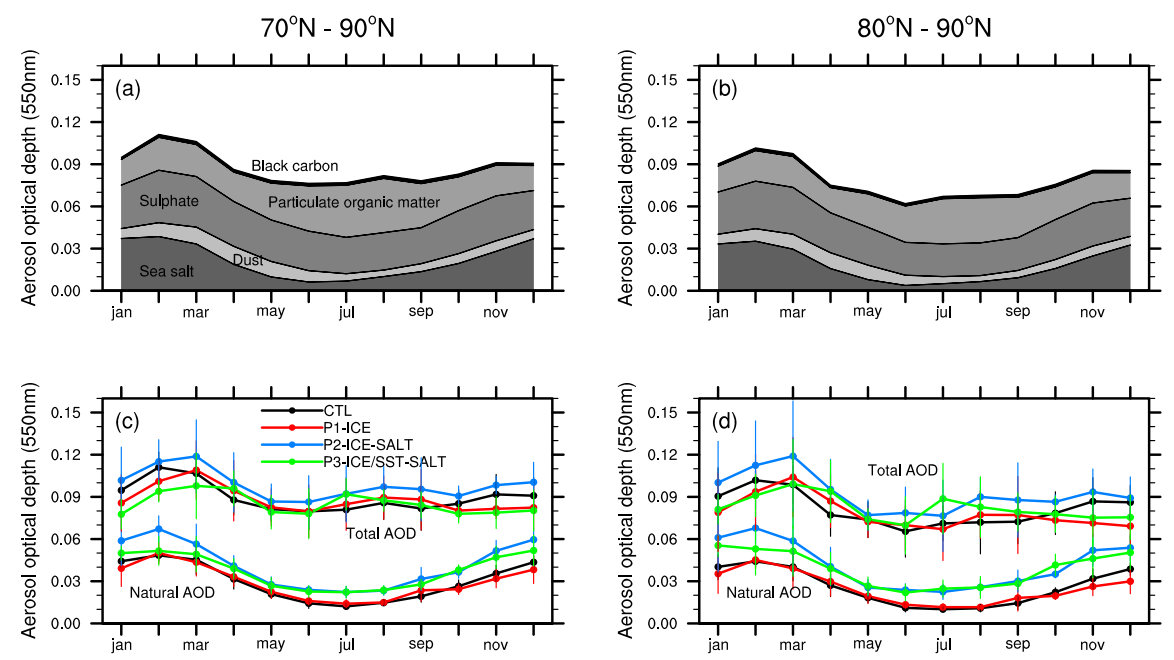

Fig. 10. (a), (b) Contribution from the five components of the aerosol burden (black carbon, particulate organic matter, sulphate, mineral dust and sea salt) to the total AOD for the CTL simulation. (c), (d) modeled Arctic natural AOD (550 nm) and total AOD (550 nm) with averages taken over ocean grid points only for the final five years of the model integrations.
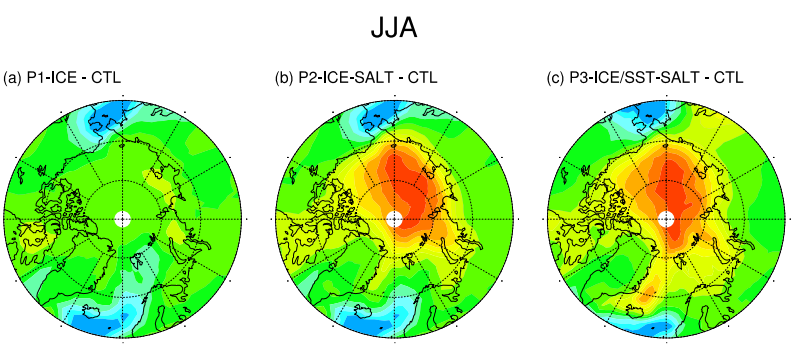

\section{DJF}
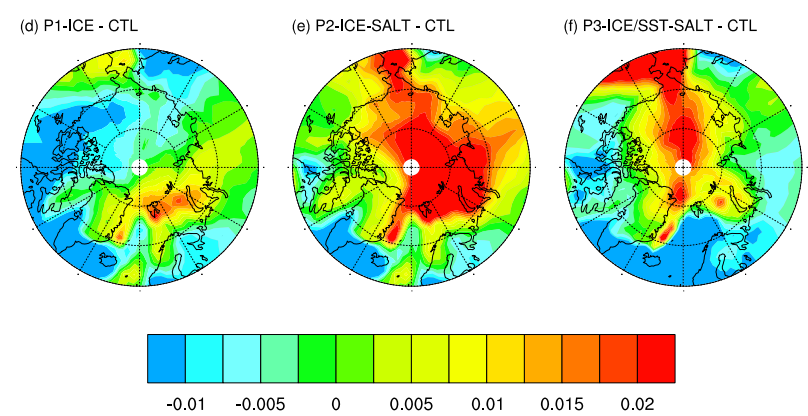

Fig. 11. Average summer (JJA) and winter (DJF) modeled difference (relative to the CTL simulation) in the natural AOD in response to changes in sea ice extent.

relatively high in autumn compared to spring. On the other hand the indirect forcing rapidly reduces between August to September suggesting that other processes, in addition to the $\mathrm{CDNC} /$ sea spray formation are involved in determining the indirect effect in the model.
It should be noted that there are large uncertainties in the current understanding of the interactions between aerosols and clouds, particularly mixed phase clouds which occur frequently in the Arctic. The model is run in an uncoupled configuration such that the prognostic aerosol fields do not directly influence the model's representation of clouds. In addition, as mentioned in Sect. 5.1 there are questions with regard to the representation of Arctic clouds in CAM-Oslo which increase the uncertainty in the estimated aerosol indirect effect. Nevertheless other studies (e.g. Garrett et al., 2004, 2009; Mauritsen et al., 2011; Lubin and Vogelmann, 2010) support the conclusion that the microphysics and the climate forcing of Arctic clouds are highly sensitive to aerosol concentration and composition. More studies are required to better understand and quantify the relationship between clouds and aerosols in the Arctic and the climate implications of this interaction.

\section{Conclusions}

The implications of a reduction in Arctic sea ice extent on sea salt aerosol emissions and the resulting natural radiative forcing has been examined through a series of model simulations using the CAM-Oslo global climate model. Over the open ocean, sea salt aerosol emissions are primarily determined by $U_{10}$ although the average $U_{10}$ over the Arctic cap was relatively insensitive to applied changes in sea ice extent and SST. This means that the prescribed changes in sea ice extent and SST were the main drivers of the modeled change in sea salt aerosol burden over the Arctic in this study.

Considering the sea ice/sea salt aerosol system in isolation, the chain of response due to a reduction in sea ice extent results in: 

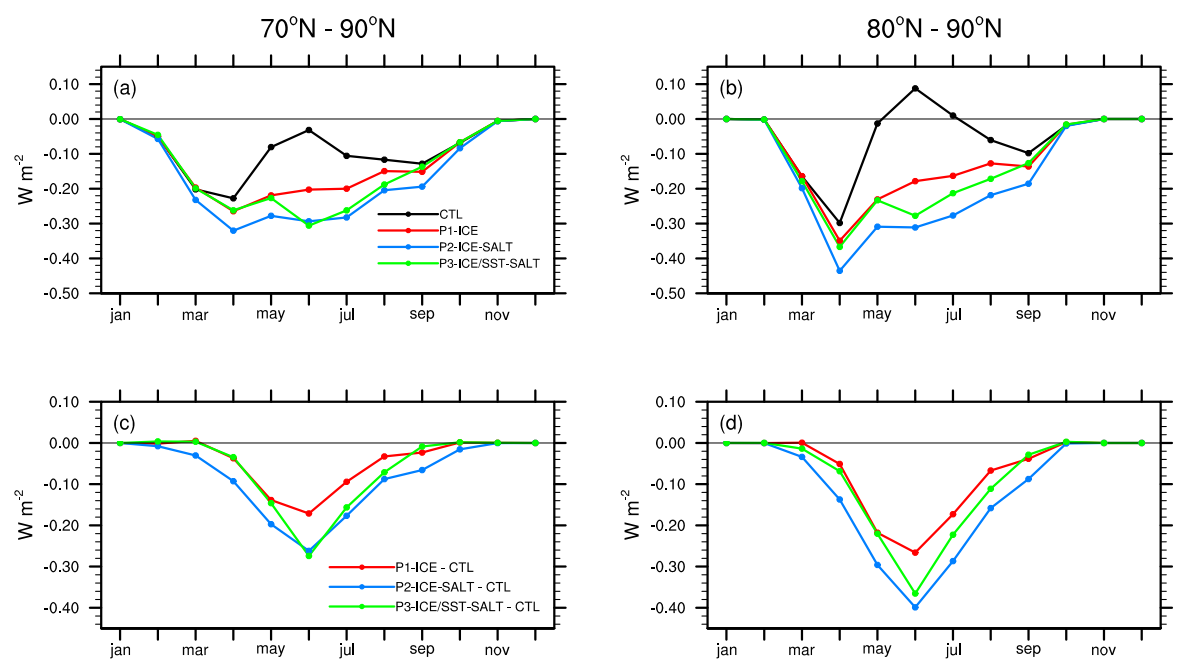

Fig. 12. (a), (b) Modeled TOA aerosol direct radiative forcing in $\mathrm{W} \mathrm{m}^{-2}$ attributed to natural aerosols. (c), (d) differences in aerosol direct radiative forcing (relative to the CTL simulation). Averages are taken using all grid points for the final five years of the model integrations.

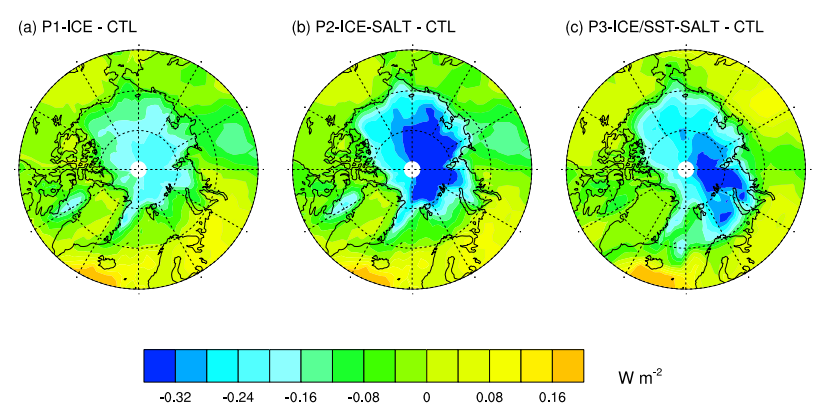

Fig. 13. Average JJA modeled TOA natural aerosol direct radiative forcing ( $\mathrm{W} \mathrm{m}^{-2}$, relative to the CTL simulation) in response to changes in sea ice extent.

- increase in sea salt aerosol emissions (by a factor of between two and three in number emission),

- increase in boundary layer and column integrated sea salt aerosol concentrations,

- increase the in the natural AOD (annual average of approximately $23 \%$ and $50 \%$ for $70-90^{\circ} \mathrm{N}$ and $80-90^{\circ} \mathrm{N}$ respectively),

- decrease in the natural aerosol radiative forcing (increase in the magnitude of the forcing). The first indirect aerosol forcing was found to be approximately 10 times the direct aerosol forcing.

The increase in the magnitude of the aerosol forcing in turn can be expected to decrease atmospheric temperatures although this was not quantified in the investigations carried out here. The model exhibited little change in wind speed when sea ice cover and SSTs were changed. This suggests that the feedback loop involving wind speed changes and sea spray emissions (Fig. 1) is not important however this conclusion is limited by how accurately the wind response to sea ice change is modeled in CAM-Oslo.

From the present model results the total sea ice-sea spray feedback is a negative feedback that works to retard Arctic climate change. One point of note from the model results is the importance of the surface albedo in determining the strength of the natural aerosol radiative forcing. This leads to the conclusion that the sea ice-sea spray feedback is strongly linked to the Arctic sea ice-albedo feedback mechanism. Most likely, the ice-sea spray feedback is not large enough to counteract the ice-albedo feedback, but it will reduce it. Furthermore, unless the effect of SST changes on sea spray emissions are considered, the ice-sea spray feed back effect is overestimated. This means that for Arctic climate simulations it is important to include both the effects of sea spray, and to use a sea spray source parameterization that responds to SST changes.

A second conclusion from the results shown here is that aerosol-cloud interactions are particularly important in the Arctic. The simple diagnostic treatment of cloud droplet number concentration used here suggests that the aerosolcloud interaction dominates over the direct aerosol effect in the Arctic, although there remains large uncertainties in these estimates. In addition, liquid water path, cloudiness and cloud radiative forcing are also strongly coupled to Arctic sea ice extent (which is not included in Fig. 1, but which CAM-Oslo will have, to some degree responded to).

It is clear from Fig. 1 that the idealized model simulations carried out in this study are only able to probe a small subset of all the processes involved in the sea ice-albedo and sea ice-sea salt aerosol feedback mechanisms, with many of 

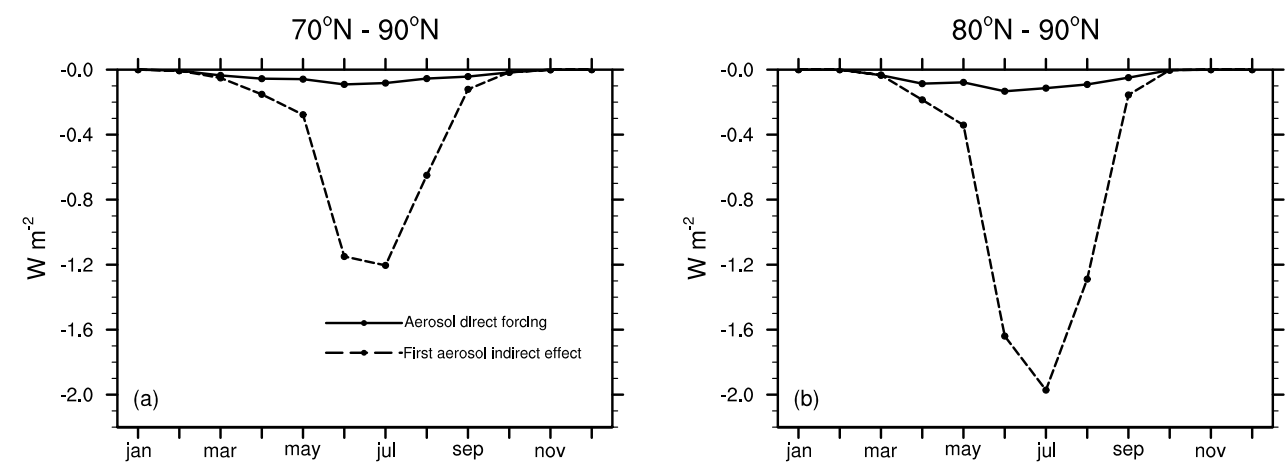

Fig. 14. Comparison of the modeled TOA aerosol direct radiative forcing and the first aerosol indirect effect for natural aerosols derived from the difference between the P2 and P1 simulations. Averages are taken using all grid points for the final five years of the model integrations.

(a) Aerosol direct forcing $\left(\mathrm{W} \mathrm{m}^{-2}\right)$

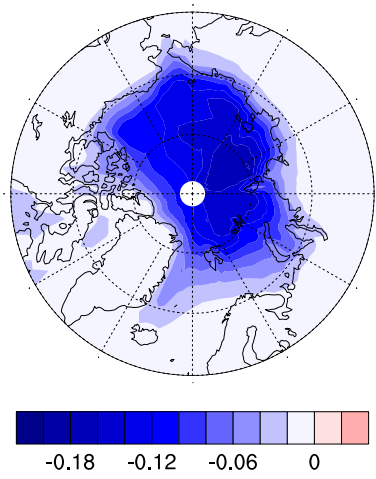

(b) SW cloud forcing $\left(\mathrm{W} \mathrm{m}^{-2}\right)$

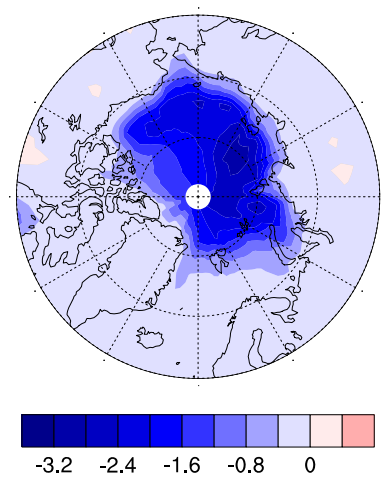

Fig. 15. Comparison of the average JJA modeled TOA natural aerosol direct radiative forcing and first natural aerosol indirect effect derived from the difference between the P2 and P1 simulations.

the coupled processes missing from the model experiments carried out in this study. Furthermore, there is a number of other external drivers that could potentially affect the system depicted in Fig. 1. These include:

- Change in Arctic anthropogenic aerosol concentration and composition, particularly due to commercial shipping through the Arctic when sea ice is reduced (Eyring et al., 2005), and possible future off shore oil and gas drilling in the high Arctic.

- The influence of black carbon aerosol on the snow/ice albedo.

- The response of the Arctic DMS cycle to changes in sea ice extent and changes in marine biology.

- Large scale atmospheric and ocean circulation changes.

- The role of primary organic sea spray emissions, which will result in aerosol particles with different cloud activation properties compared to sea salt particles, and which may be dependent also on changes in marine microbiology in addition to changes in sea ice and SST. Recent measurements are indicating a substantial primary marine organic aerosol source, particularly in the sub-micron size range (Facchini et al., 2008; O'Dowd et al., 2008; Sciare et al., 2009; Hultin et al., 2010). This aerosol source may play an important role globally (Spracklen et al., 2008) but was not included here because current source parameterizations have not yet been comprehensively evaluated, particularly in the Arctic.

Subsequent studies are required both to quantify the role of particular processes and to better understand to coupling of these terms. It is clear then that the Arctic climate is a complex and highly coupled system which therefore poses a challenge for the current generation of Earth system models.

Acknowledgements. This study is part of the interdisciplinary climate project GRACE (Greenhouse Arctic ocean and Climate Effects of aerosols), financed by the Swedish Research Council (contract 2007-8362). We acknowledge the modeling groups, the Program for Climate Model Diagnosis and Intercomparison (PCMDI) and the WCRP's Working Group on Coupled Modelling (WGCM) for their roles in making available the WCRP CMIP3 multi-model dataset. Support of this dataset is provided by the Office of Science, US Department of Energy. The authors would like to thank Anders Engström (MISU) for assistance with retrieving the the ECMWF ERA-Interim data used in this study. The research by T. Iversen, A. Kirkevåg and $\varnothing$. Seland was supported by the projects NorClim (Norwegian Research Council Grant 178246) and POLARCAT (Norwegian Research Council Grant 175916). This work is supported by the Bert Bolin Center for Climate Research (http://www.bbcc.su.se/).

Edited by: E. Vignati 


\section{References}

Blanchard, D. C. and Woodcock, A. H.: Bubble formation and modification in the sea and its meteorological significance, Tellus, 9, 145-158, 1957.

Carslaw, K. S., Boucher, O., Spracklen, D. V., Mann, G. W., Rae, J. G. L., Woodward, S., and Kulmala, M.: A review of natural aerosol interactions and feedbacks within the Earth system, Atmos. Chem. Phys., 10, 1701-1737, doi:10.5194/acp-10-17012010, 2010.

Clarke, A. D., Owens, S. R., and Zhou, J.: An ultrafine sea-salt flux from breaking waves: Implications for cloud condensation nuclei in the remote marine atmosphere, J. Geophys. Res., 111, D06202, doi:10.1029/2005JD006565, 2006.

Collins, W. D., Rasch, P. J., Boville, B. A., Hack, J. J., McCaa, J. R., Williamson, D. L., Briegleb, B. P., Bitz, C. M., Lin, S.-J., and Zhang, M.: The Formulation and atmospheric simulation of the Community Atmospheric Model Version 3 (CAM3), J. Climate, 19, 2144-2161, 2006.

Comiso, J. C.: Large scale characteristics and variability of the global sea ice cover, in: Sea Ice - An Introduction to its Physics, Biology, Chemistry, and Geology, edited by: Thomas, D. and Dieckmann, G., 112-142, Blackwell Science, Oxford, UK, 2003.

Dee, D. P. and Uppala, S.: Variational bias correction of satellite radiance data in the ERA-Interim reanalysis, Q. J. Roy. Meteorol. Soc., 135, 1830-1841, 2009.

Dentener, F., Kinne, S., Bond, T., Boucher, O., Cofala, J., Generoso, S., Ginoux, P., Gong, S., Hoelzemann, J. J., Ito, A., Marelli, L., Penner, J. E., Putaud, J.-P., Textor, C., Schulz, M., van der Werf, G. R., and Wilson, J.: Emissions of primary aerosol and precursor gases in the years 2000 and 1750 prescribed data-sets for AeroCom, Atmos. Chem. Phys., 6, 4321-4344, doi:10.5194/acp6-4321-2006, 2006.

Deser, C., Tomas, R., Alexander, M., and Lawerence, D.: The Seasonal Atmospheric Response to Projected Arctic Sea Ice Loss in the Late Twenty-First Century, J. Climate, 23, 333-351, doi:10.1175/2009JCLI3053.1, 2010.

Deweaver, E. T. and Bitz, C. M.: Atmospheric Circulation and Its Effect on Arctic Sea Ice in CCSM3 Simulations at Medium and High Resolution, J. Climate, 19, 2415-2436, 2006.

Eyring, V., Köhler, H. W., Lauer, A., and Lemper, B.: Emissions from international shipping: 2. Impact of future technologies on scenarios until 2050, J. Geophys. Res., 110, D17306, doi:10.1029/2004JD005620, 2005.

Facchini, M. C., Rinaldi, M., Decesari, S., Carbone, C., Finessi, E., Mircea, M., Fuzzi, S., Ceburnis, D., Flanagan, R., Nilsson, E. D., de Leeuw, G., Martino, M., Woeltjen, J., and O'Dowd, C. D.: Primary submicron marine aerosol dominated by insoluble organic colloids and aggregates, Geophys. Res. Lett., 35, L17814, doi:10.1029/2008GL034210, 2008.

Gabric, A. J., Qu, B., Matrai, P., and Hirst, A. C.: The simulated response of dimethylsulfide production in the Arctic Ocean to global warming, Tellus, 57B, 391-403, 2005.

Garrett, T. J., Zhao, C., Dong, X., Mace, G. G., and Hobbs, P. V.: Effects of varying aerosol regimes on low-level Arctic stratus, Geophys. Res. Lett., 31, L17105, doi:10.1029/2004GL019928, 2004.

Garrett, T. J., Maestas, M. M., Krueger, S. K., and Schmidt, C. T.: Acceleration by aerosol of a radiative-thermodynamic cloud feedback influencing Arctic surface warming, Geophys.
Res. Lett., 36, L19804, doi:10.1029/2009GL040195, 2009.

Hack, J. J., Caron, J. M., Danabasoglu, G., Oleson, K. W., Bitz, C. M., and Truesdale, J. E.: CCSM-CAM3 Climate Simulation Sensitivity to Changes in Horizontal Resolution, J. Climate, 19, 2267-2289, 2006.

Hatzianastassiou, N., Katsoulis, B., and Vardavas, I.: Sensitivity analysis of aerosol direct radiative forcing in ultraviolet-visible wavelengths and consequences for the heat budget, Tellus B, 56, 368-381, doi:10.1111/j.1600-0889.2004.00110.x, 2004.

Holland, M. M., Bitz, C. M., and Tremblay, B.: Future abrupt reductions in the summer Arctic sea ice, Geophys. Res. Lett., 33, L23503, doi:10.1029/2006GL028024, 2006.

Hultin, K. A. H., Nilsson, E. D., Krejci, R., Mårtensson, E. M., Ehn, M., Hagström, Å., and de Leew, G.: In situ laboratory sea spray production during the Marine Aerosol Production 2006 cruise on the northeastern Atlantic Ocean, J. Geophys. Res., 115, D06201, doi:10.1029/2009JD012522, 2010.

Hurrell, J. W., Hack, J. J., Phillips, A., Caron, J. M., and Yin, J.: The Dynamical Simulation of the Community Atmosphere Model Version 3, J. Climate, 19, 2162-2183, doi:10.1175/JCLI3762.1, 2005.

Hurrell, J. W., Hack, J. J., Shea, D., Caron, J. M., and Rosinski, J. M.: A new sea surface temperature and sea ice boundary data set for the Community Atmosphere Model, J. Climate, 21, 51455153, doi:10.1175/2008JCLI2292.1, 2008.

Intrieri, J. M., Shupe, M., Uttal, T., and McCarty, B. J.: An annual cycle of Arctic cloud characteristics observed by radar and lidar at SHEBA, J. Geophys. Res., 107, 8039, doi:10.1029/2000JC000423, 2002.

Iversen, T. and Seland, Ø.: A scheme for process-tagged SO_4 and $\mathrm{BC}$ aerosols in NCAR CCM3: Validation and sensitivity to cloud processes, J. Geophys. Res., 107(D24), 4751, doi:10.1029/2001JD000885, 2002.

Jones, A., Haywood, J. M., and Boucher, O.: Aerosol forcing, climate response and climate sensitivity in the Hadley Centre climate model, J. Geophys. Res., 112, D20211, doi:10.1029/2007JD008688, 2007.

Kay, J. E. and Gettelman, A.: Cloud influence on and response to seasonal Arctic sea ice loss, J. Geophys. Res., 114, D18204, doi:10.1029/2009JD011773, 2009.

Kellog, W. W.: Climatic feedback mechanisms involving the polar regions, in: Climate of the Arctic, edited by Weller, G. and Bowling, S. A., pp. 111-116, Geophysical Institute, Fairbanks, AK, 1973.

Kinne, S., Schulz, M., Textor, C., Guibert, S., Balkanski, Y., Bauer, S. E., Berntsen, T., Berglen, T. F., Boucher, O., Chin, M., Collins, W., Dentener, F., Diehl, T., Easter, R., Feichter, J., Fillmore, D., Ghan, S., Ginoux, P., Gong, S., Grini, A., Hendricks, J., Herzog, M., Horowitz, L., Isaksen, I., Iversen, T., Kirkevåg, A., Kloster, S., Koch, D., Kristjansson, J. E., Krol, M., Lauer, A., Lamarque, J. F., Lesins, G., Liu, X., Lohmann, U., Montanaro, V., Myhre, G., Penner, J., Pitari, G., Reddy, S., Seland, O., Stier, P., Takemura, T., and Tie, X.: An AeroCom initial assessment optical properties in aerosol component modules of global models, Atmos. Chem. Phys., 6, 1815-1834, doi:10.5194/acp-6-1815-2006, 2006.

Kirkevåg, A. and Iversen, T.: Global direct radiative forcing by process-parameterized aerosol optical properties, J. Geophys. Res., 107, 4433, doi:10.1029/2001JD000886, 2002. 
Kirkevåg, A., Iversen, T., Seland, Ø., and Kristjansson, J. E.: Revised schemes for aerosol optical parameters and cloud condensation nuclei in CCM-Oslo, Tech. rep., Department of Geosciences, University of Oslo, institute Report Series, 2005.

Kirkevåg, A., Iversen, T., Kristjansson, J. E., Seland, Ø., and Debernard, J. B.: On the additivity of climate response to anthropogenic aerosols and $\mathrm{CO} \_2$, and the enhancement of future global warming by carbonaceous aerosols, Tellus, 60A, 513527, doi:10.1111/j.1600-0870.2008.00308.x, 2008a.

Kirkevåg, A., Iversen, T., Seland, Ø., Debernard, J. B., Storelvmo, T., and Kristjansson, J. E.: Aerosol-cloud-climate interactions in the climate model CAM-Oslo, Tellus, 60A, 492-512, doi:10.1111/j.1600-0870.2008.00313.x, 2008b.

Koch, D., Schulz, M., Kinne, S., McNaughton, C., Spackman, J. R., Balkanski, Y., Bauer, S., Berntsen, T., Bond, T. C., Boucher, O., Chin, M., Clarke, A., De Luca, N., Dentener, F., Diehl, T., Dubovik, O., Easter, R., Fahey, D. W., Feichter, J., Fillmore, D., Freitag, S., Ghan, S., Ginoux, P., Gong, S., Horowitz, L., Iversen, T., Kirkevåg, A., Klimont, Z., Kondo, Y., Krol, M., Liu, X., Miller, R., Montanaro, V., Moteki, N., Myhre, G., Penner, J. E., Perlwitz, J., Pitari, G., Reddy, S., Sahu, L., Sakamoto, H., Schuster, G., Schwarz, J. P., Seland, Ø., Stier, P., Takegawa, N., Takemura, T., Textor, C., van Aardenne, J. A., and Zhao, Y.: Evaluation of black carbon estimations in global aerosol models, Atmos. Chem. Phys., 9, 9001-9026, doi:10.5194/acp-9-9001-2009, 2009.

Kristjansson, J. E.: Studies of the aerosol indirect effect from sulfate and black carbon aerosols, J. Geophys. Res., 107, 4246, doi:10.1029/2001JD000887, 2002.

Lemke, P., Ren, J., Alley, R. B., Allison, I., Carrasco, J., Flato, G., Fujii, Y., Kaser, G., Mote, P., Thomas, R. H., and Zhang, T.: Observations: Changes in Snow, Ice and Frozen Ground, in: Climate Change 2007: The Physical Science Basis. Contribution of Working Group I to the Fourth Assessment Report of the Intergovernmental Panel on Climate Change, chap. 4, Cambridge University Press, Cambridge, United Kingdom and New York, NY, USA, 2007.

Lewis, E. R. and Schwartz, S. E.: Sea salt aerosol production: mechanisms, methods, measurements and models - a critical review, in: Geophysical monograph Vol. 152, American Geophysical Union, Washington DC, 2004.

Lubin, D. and Vogelmann, A. M.: Observational quantification of a total aerosol indirect effect in the Arctic, Tellus, 62B, 181-189, doi:10.1111/j.1600-0889.2010.00460.x, 2010.

Magnusdottir, G., Deser, C., and Saravanan, R.: The Effects of North Atlantic SST and Sea Ice Anomalies on the Winter Circulation in CCM3. Part I: Main Features and Storm Track Characteristics of the Response, J. Climate, 17, 857-876, 2004.

Mårtensson, E. M., Nilsson, E. D., Leeuw, G. D., Cohen, L. H., and Hansson, H.-C.: Laboratory simulations and parameterization of the primary marine aerosol production, J. Geophys. Res., 108, 4297, doi:10.1029/2002JD002263, 2003.

Mårtensson, E. M., Tunved, P., Korhonen, H., and Nilsson, E. D.: The role of sea-salt emissions in controlling the marine Aitken and accumulation mode aerosol: a model study, Tellus B, 62, 259-279, 2010.

Mauritsen, T., Sedlar, J., Tjernström, M., Leck, C., Martin, M., Shupe, M., Sjogren, S., Sierau, B., Persson, P. O. G., Brooks, I. M., and Swietlicki, E.: An Arctic CCN-limited cloud-aerosol regime, Atmos. Chem. Phys., 11, 165-173, doi:10.5194/acp-11165-2011, 2011.

Monahan, E. C. and Muircheartaigh, I.: Optimal power-law description of oceanic whitecap coverage dependence on wind speed, J. Phys. Oceanogr., 10, 2094-2099, 1980.

Monahan, E. C., Spiel, D. E., and Davidson, K. L.: A model of marine aerosol generation via whitecaps and wave disruption, in: Oceanic Whitecaps, edited by Monahan, E. C. and MacNiochaill, pp. 167-193, D. Reidel, 1986.

Mortiz, R. E., Bitz, C. M., and Steig, E. J.: Dynamics of Recent Climate Change in the Arctic, Science, 297, 1497, doi:10.1126/science.1076522, 2002.

Nilsson, E. D.: Planetary boundary layer structure and air mass transport during the International Arctic Ocean Expedition 1991, Tellus, 48B, 178-196, 1996.

Nilsson, E. D. and Barr, S.: Effects of Synoptic Patterns on Atmospheric Chemistry and Aerosols during the Arctic Ocean Expedition 1996, J. Geophys. Res., 106, 32069-32086, doi:10.1029/2000JD900376, 2001.

Nilsson, E. D. and Leck, C.: A pseudo-Lagrangian study of the sulfur budget in the remote Arctic marine boundary layer, Tellus, 54B, 213-230, 2002.

Nilsson, E. D. and Rannik, Ü.: Turbulent aerosol fluxes over the Arctic Ocean 1. Dry deposition over sea and pack ice, J. Geophys. Res., 106(D23), 32125-32137, 2001.

Nilsson, E. D., Rannik, Ü., and Høakansson, M.: Surface energy budget over the central Arctic Ocean during late summer and early freez up, J. Geophys. Res., 106, 32187-32206, 2001a.

Nilsson, E. D., Rannik, Ü., Swietlicki, E., Leck, C., Aalto, A. A., Zhou, J., and Norman, M.: Turbulent aerosol fluxes over the Arctic Ocean 2. Wind-driven sources from the sea, J. Geophys. Res., 106 (D23), 32139-32154, 2001b.

Nilsson, E. D., Mårtensson, E. M., Van Ekeren, J. S., de Leeuw, G., Moerman, M., and O’Dowd, C.: Primary marine aerosol emissions: size resolved eddy covariance measurements with estimates of the sea salt and organic carbon fractions, Atmos. Chem. Phys. Discuss., 7, 13345-13400, doi:10.5194/acpd-713345-2007, 2007.

O’Dowd, C. D., Langmann, B., Varghese, S., Scannell, C., Ceburnis, D., and Facchini, M. C.: A combined organic-inorganic sea-spray source function, Geophys. Res. Lett., 35, L01801, doi:10.1029/2007GL030331, 2008.

Penner, J. E., Quaas, J., Storelvmo, T., Takemura, T., Boucher, O., Guo, H., Kirkevåg, A., Kristjánsson, J. E., and Seland, Ø.: Model intercomparison of indirect aerosol effects, Atmos. Chem. Phys., 6, 3391-3405, doi:10.5194/acp-6-3391-2006, 2006.

Persson, P. O. G., Fairall, C. W., Andreas, E. L., Guest, P. S., and Perovich, D. K.: Measurements near the Atmospheric Surface Flux Group tower at SHEBA: Near-surface conditions and surface energy budget, J. Geophys. Res., 107, 8045, doi:10.1029/2000JC000705, 2002.

Pierce, J. R. and Adams, P. J.: Global evaluation of CCN formation by direct emission of sea salt and growth of ultrafine sea salt, J. Geophys. Res., 111, D06203, doi:10.1029/2005JD006186, 2006.

Quaas, J., Ming, Y., Menon, S., Takemura, T., Wang, M., Penner, J. E., Gettelman, A., Lohmann, U., Bellouin, N., Boucher, O., Sayer, A. M., Thomas, G. E., McComiskey, A., Feingold, G., Hoose, C., Kristjánsson, J. E., Liu, X., Balkanski, Y., Donner, L. J., Ginoux, P. A., Stier, P., Grandey, B., Feichter, J., Sednev, I., 
Bauer, S. E., Koch, D., Grainger, R. G., Kirkevåg, A., Iversen, T., Seland, Ø., Easter, R., Ghan, S. J., Rasch, P. J., Morrison, H., Lamarque, J.-F., Iacono, M. J., Kinne, S., and Schulz, M.: Aerosol indirect effects general circulation model intercomparison and evaluation with satellite data, Atmos. Chem. Phys., 9, 8697-8717, doi:10.5194/acp-9-8697-2009, 2009.

Quinn, P. K., Shaw, G., Andrews, E., Duttin, E. G., Ruoho-Airola, T., and Gong, S. L.: Arctic haze: current trends and knowledge gaps, Tellus, 59B, 99-114, 2007.

Quinn, P. K., Bates, T. S., Baum, E., Doubleday, N., Fiore, A. M., Flanner, M., Fridlind, A., Garrett, T. J., Koch, D., Menon, S., Shindell, D., Stohl, A., and Warren, S. G.: Short-lived pollutants in the Arctic: their climate impact and possible mitigation strategies, Atmos. Chem. Phys., 8, 1723-1735, doi:10.5194/acp8-1723-2008, 2008.

Schulz, M., Textor, C., Kinne, S., Balkanski, Y., Bauer, S., Berntsen, T., Berglen, T., Boucher, O., Dentener, F., Guibert, S., Isaksen, I. S. A., Iversen, T., Koch, D., Kirkevåg, A., Liu, X., Montanaro, V., Myhre, G., Penner, J. E., Pitari, G., Reddy, S., Seland, Ø., Stier, P., and Takemura, T.: Radiative forcing by aerosols as derived from the AeroCom present-day and pre-industrial simulations, Atmos. Chem. Phys., 6, 5225-5246, doi:10.5194/acp-6-5225-2006, 2006.

Sciare, J., Favez, O., Sarda-Esteve, R., Oikonomou, K., Cachier, H., and Kazan, V.: Long-term observations of carbonaceous aerosols in the Austral Ocean atmosphere: Evidence of a biogenic marine organic source, J. Geophys. Res., 114, D15302, doi:10.1029/2009JD011998, 2009.

Seland, Ø., Iversen, T., Kirkevåg, A., and Storelvmo, T.: Aerosolclimate interactions in the CAM-Oslo atmospheric GCM and investigation of associated basic shortcomings, Tellus, 60A, 459491, doi:10.1111/j.1600-0870.2008.00318.x, 2008.

Serreze, M. C. and Francis, J. A.: The Arctic amplification debate, Climate Change, 76, 241-264, doi:10.1007/s10584-005-9017-y, 2006.

Serreze, M. C., Holland, M. M., and Stroeve, J.: Perspectives on the Arctic's Shrinking Sea-Ice Cover, Science, 315, 1533, doi:10.1126/science.1139426, 2007.

Sewall, J. O. and Sloan, L. C.: Disappearing Arctic sea ice reduces available water in the American west, Geophys. Res. Lett., 31, L06209, doi:10.1029/2003GL019133, 2004.
Shaw, G.: The Arctic haze phenomenon, Bulletin of the American Meteorological Society, 76, 2403-2413, 1995.

Singarayer, J. S., Bamber, J. L., and Valdes, P. J.: Twenty-FirstCentury Climate Impacts from a Declining Arctic Sea Ice Cover, J. Climate, 19, 1109-1125, 2006.

Spracklen, D. V., Arnold, S. R., Sciare, J., Carslaw, K. S., and Pio, C.: Globally significant oceanic source of organic carbon aerosol, Geophys. Res. Lett., 35, L12811, doi:10.1029/2008GL033359, 2008.

Stroeve, J., Holland, M. M., Meier, W., Scambos, T., and Serreze, M.: Arctic sea ice decline: Faster than forecast, Geophys. Res. Lett., 34, L09501, doi:10.1029/2007GL029703, 2007.

Textor, C., Schulz, M., Guibert, S., Kinne, S., Balkanski, Y., Bauer, S., Berntsen, T., Berglen, T., Boucher, O., Chin, M., Dentener, F., Diehl, T., Easter, R., Feichter, H., Fillmore, D., Ghan, S., Ginoux, P., Gong, S., Grini, A., Hendricks, J., Horowitz, L., Huang, P., Isaksen, I., Iversen, I., Kloster, S., Koch, D., Kirkevåg, A., Kristjansson, J. E., Krol, M., Lauer, A., Lamarque, J. F., Liu, X., Montanaro, V., Myhre, G., Penner, J., Pitari, G., Reddy, S., Seland, Ø., Stier, P., Takemura, T., and Tie, X.: Analysis and quantification of the diversities of aerosol life cycles within AeroCom, Atmos. Chem. Phys., 6, 1777-1813, doi:10.5194/acp-61777-2006, 2006.

Twomey, S.: The influence of pollution of the shortwave albedo of clouds, J. Atmos. Sci., 34, 1149-1152, 1977.

Vavrus, S.: The Impact of Cloud Feedbacks on Arctic Climate under Greenhouse Forcing, J. Climate, 17, 603-615, 2004.

Walsh, J. E., Chapman, W. L., and Portis, D. H.: Arctic Cloud Fraction and Radiative Fluxes in Atmospheric Reanalyses, J. Climate, 22, 2316-2334, 2009.

Wang, J., Zhang, J., Watanabe, E., Ikeda, M., Mizobata, K., Walsh, J. E., Bai, X., and Wu, B.: Is the Dipole Anomaly a major driver to record lows in Arctic summer sea ice extent?, Geophys. Res. Lett., 36, L05706, doi:10.1029/2008GL036706, 2009.

Winton, M.: Surface Albedo Feedback Estimates for the AR4 Climate Models, J. Climate, 19, 359-365, 2006.

Winton, M.: Sea ice-albedo feedback and nonlinear Arctic climate change, in: Arctic Sea Ice Decline: Observations, Projections, Mechanisms and Implications, Geophysical Monograph Series, edited by: Deweaver, E. T., Bitz, C. M., and Tremblay, L. B., vol. 180, pp. 111-131, American Geophysical Union (Washington DC), 2008. 